\title{
Effect of Spirituality, Demographics, and Culture on Career Satisfaction, Organizational Fairness Climate, and Affective Commitment in Pakistani Organization: The Mediatory Role of Ethical Leadership
}

\author{
Muhammad Owais \\ Research Scholar \\ Karachi University Business School \\ University of Karachi, Pakistan \\ E-mail: m.owais999@hotmail.com \\ Dr. Danish Ahmed Siddiqui \\ Associate Professor \\ Karachi University Business School \\ University of Karachi, Pakistan \\ E-mail: daanish79@hotmail.com
}

Received: Jan. 4, $2021 \quad$ Accepted: Feb. 5, $2021 \quad$ Online published: Feb. 14, 2020

doi:10.5296/ijhrs.v11i1.18305 URL: https://doi.org/10.5296/ijhrs.v11i1.18305

\begin{abstract}
The lens through which followers experience the ethical dimension of leadership itself it is argued is likely distorted by a followers' level in the hierarchy. In this regard, ethical leadership may be better conceptualized as an intermediary through which follower status contributes to these desirable outcomes. This research expands the literature about the causes, consequences, and the unique role of ethical leadership in the workplace. In particular, we examine the mediated model of ethical leadership in the effect of individualism, spirituality, as well as demographics on organizational outcomes like 1. Organization' s fairness climate (CF), 2. Affective commitment (AC), and 3. Career satisfaction (CS). Drawing on the work of Pucic (2015), we argue that demographics like Job, experience, Age, Education, Position,
\end{abstract}


and Working Hour of employees affect their perception of ethical leadership (EL) in the organization, and this perception, in turn, affect the three above mentioned outcomes. In the same way, spirituality and individualistic (IND) cultures also influence these outcomes through EL. Spirituality was further sub-classified into Spiritual Believe (SB), Coping (SC), Experience (SE), and Practices (SP). Empirical validity was established by conducting a survey using a close-ended questionnaire. Data was collected from 500 employees and analyzed using confirmatory factor analysis and structured equation modeling. The results suggested that Ethical leadership, individualistic culture, and years of experience have a positive and significant effect on all three outcomes i.e. AC, CF, CS. Moreover, Education and Spiritual Believe seem to have a positive impact on AC. Similarly, Spiritual Experience also has a positive effect on CF. Surprisingly, position and Spiritual Practices seem to have a negative and significant impact on career satisfaction. Moreover, Education, individualism, and position also seem to be positively impacting ethical leadership. Hence, EL positively mediates the effect of education, individualism, and position on $\mathrm{AC}, \mathrm{CF}$, and $\mathrm{CS}$ respectively. Implications for theory and practice are discussed.

Keywords: ethical leadership, affective commitment, career satisfaction, fairness climate

\section{Introduction}

\subsection{The Background of Study}

The last 20 years have seen drastic ethical and behavioral rises complications with the organization. Research shows that sometimes the process of Ethical Decision Making (EDM) develops as a significant concern among the relationships of leader followers. Following the global financial crisis of 2007, service sector organizations are continually facing numerous problems in establishing cost-effective occurrences in a market competition(Tschetter, 2014). The literature on organizational change management demonstrates that the model of ethical leadership has developed as a significant distinction between successful and unsuccessful organizations to overcome those operational problems over the past few years(Stewart Wherry, 2012).

Ethical leadership analysis notes that a leader's ethical character expressed by values of justice, integrity, and respect for subordinates plays a significant role in promoting and improving desired organizational outcomes. Ethical practitioners, as a source of motivation for subordinates, shape their actions and perceptions of people's and organizational gains. Even the global financial and economic crisis, to some extent, would suggest that focusing only on the leader could be dangerous. The politicians implicated in these controversies may have been viewed at some stage by at least some of their supporters as 'good leaders. Literature cries out on the need for studies into the overt as well as the subtle impact of EL on managerial actions and how lower levels in the hierarchy view ethical leadership. The study of organizational culture and climate seek to explain how organizational members make sense of their environment and serve as the foundational elements used to describe organizational phenomenon (Schneider, 2000). Reave (2005) conducted an exhaustive review of the literature and noted that spirituality expresses itself in the embodiment of spiritual values (i.e., integrity, trust, ethical influence, honest communication, and humility) and 
spiritual behaviors (i.e., demonstrating respect, treating others fairly, expressing care and concern, listening responsively, appreciating the contributions of others, and engaging in spiritual practice).

The study of leadership has been one of the most passionate endeavors of mankind. Although it was there are several branches of leadership in the organizational sciences, most of them leadership Basic definition includes the mechanism of control (Yolk, 2010).

In the leader-follower dyad, taking the perspective to constructive organizational psychology, there are empirical factors that can help to understand good results that have little to do with the role of the leader. It is argued that the prism by which followers view the ethical component of leadership itself is possibly skewed by the level of a follower in the hierarchy itself. If substantiated, this halo effect will contribute to overestimating the importance of ethical leadership and because of this discussion. Indeed, companies should be careful. As an intermediary by which follower status leads to these desirable effects, ethical leadership can be best conceptualized. To date, the literature has failed to delineate the influence of the own role of followers in the organizational hierarchy on the modelling taking place, particularly when the modelling involves an ethical component.

In the workplace, in the execution of a given mission, the word leadership frequently conjures visions of impactful executive personalities directing subordinate human resources. The common characteristic of these organizational figures is that they have more organizational endowments that distinguish them from their subordinates, namely, more strength, more authority and more control, as a result of their organizational rank or position. Social cognitive theory asserts that when a leader is capable, these above endowments should prompt subordinates to function in the way that the leader models (Bandura 1986). However, variations in interpretation due in part to differences in position between the follower and the leader can potentially 'cloud' any of the modelling happening. Tension will manifest as a result of this distinction particularly when it is the ethical component of leadership that is modelled (Trevin o et al. 2008; Mayer et al. 2009) Everyone who by definition has less rank than their leaders may differ in their views of their leader solely as a function of their own level in the organizational hierarchy, according to the social identity theory 'subordinates' (Brewer and Brown 1998; Turner and Tajfel 1986). This latter understanding is extremely troublesome for organizations and leaders trying to retain a happy and dedicated workforce through the ethical leade process in an environment of corporate justice In this respect, the sincerity, dignity and justice of a leader with his/her subordinates, all components of the ethical dimension of leadership and all positive examples to lead by, serve as a bridge linking the rank of a follower to meaningful organizational performance. Thus, the influence of the rank or position of a follower becomes an integral element in understanding the principle of ethical leadership and in understanding some of the shortcomings of 'leading by example'

\subsection{Problem Statement}

Leadership moved from traits theory and charismatic leadership towards more widespread and general perspectives by taking in organizational reflection processes and leadership behavior as well as increased interactions between the subordinates and leaders (Lowrey, 
2014). It investigated that transformational leadership provide clear vision, friendly and supportive working environment to their employee. In the result, employees feel strongly satisfied and perform their duties with all their satisfaction. In the context of Pakistani organization there are so uncertainties regarding the career because higher level employees want to disgrace their subordinates and try to demotivate them therefore every employee has a fear of job loosing and not satisfy moreover compensation packages are also a variable that may affect faculty job satisfaction and thus affect intentions of departure.

\subsection{Gap Analysis}

Researchers developed the philosophical and methodological structure for ethical leadership and showed its utility for forecasting important effects in the workplace, such as the perceived efficacy of leaders, the happiness of followers with their boss, commitment, and readiness of followers to disclose management problems. This problem has now started to be

raised by several scholars from many management ranks (Trevin ?? o et al. 2008; Mayer et al. 2009). Mayer et al. (2009) discovered that both top management and supervisory ethical leadership were positively linked to the corporate citizenship actions (OCB) of a group and negatively related to deviance at the group stage. This indicates major implications of ethical leadership from the complex history of workers and may not connect the views of adherents to their own respective rank or position in the hierarchy. Therefore, there is an awareness gap about how workers of different experiences view ethical leadership.

In this regard, Pucic (2015) explored via the mediating impact of ethical leadership, follower status affects workplace performance. Findings suggested that the position of a follower was favorably correlated with ethical leadership expectations, and secondly, that ethical leadership functioned as a partial mediator between rank/status and favorable effects in the workplace, such as the environment of organizational justice, job happiness and affective commitment of followers.

However, they focused mostly on followers' demographic characteristics, especially their position or rank, there may be other important influences in like spirituality and culture that were not covered before. Hence, Drawing on the work of Pucic (2015), we argue that demographics like Job, experience, Age, Education, Position, and Working Hour of employees affect their perception of ethical leadership (EL) in the organization, and this perception, in turn, affect the three above mentioned outcomes. In the same way, spirituality and individualistic (IND) cultures also influence these outcomes through EL.

This is a novel attempt as no previous study attempted to combine spirituality, and culture along with demographics as an antecedents in the mediating role of ethical leadership in employees based outcomes. Moreover, no previous study offered to explain this in Pakistani context. Hence, this would further extend the research frontier and provided a much-needed generalization.

\subsection{Research Objectives}

The purpose of this research is to identify the causes of creating Gap between high level 
employees with their subordinates however subordinates plays a significant role in promoting and improving desired organizational outcomes moreover it is also helpful to investigate ethical leadership as an important contextual factor contributing toward subordinates. This study examines the mediated model of ethical leadership in the effect of individualism, spirituality, as well as demographics on organizational outcomes like 1. Organization's fairness climate (CF), 2. Affective commitment (AC), and 3. Career satisfaction (CS). Spirituality was further sub-classified into Spiritual Believe (SB), Coping (SC), Experience (SE), and Practices (SP). This research is intended to investigate ethical leadership as an important contextual factor contributing toward subordinates. This research is conducted for the purpose of finding the gaps between leader and their subordinates.

The more explicit objectives are listed below:

1) To determine the relationship between ethical leadership and organizational climate

2) To determine mediating effect of Ethical leadership on career satisfaction

3) To determine whether the spirituality have impact on employee performance

4) To evaluate how demographics has significant in organization performance

5) To determine the relationship between career satisfaction and employee commitment.

\subsection{Significance}

The research is significant because organizations strive to maintain their pleasant organizational culture for its employees. Therefore, the current research enables to identify certain ways to develop the positive relationship with the factors which can help in improving employee performance and organizational performance. This research will not only evaluate the outcomes of Spirituality, Demographics, and Culture on Career Satisfaction, Organizational Fairness Climate, and Affective Commitment but will also recommend ways to improve relationship between these components in order to increase performance.

\section{Theoretical Framework}

\subsection{Ethical leadership}

Ethical leadership describing it as a question of intellectual integrity, moral faith, correct values / beliefs and inward-looking decision-making(Kanungo \& Mendonca, 1996). (Spears, 2010)accepted that ethical leadership is about helping colleagues, managing their interpersonal disputes and motivating them to do the best things in the correct manner. The most detailed ethical leadership approach by combining both the spiritual individual and boss' aspects. In particular, (Brown \& Treviño, 2006)offering a multidimensional conceptualization described EL as a realistic show of normatively acceptable behavior through personal practices as well as interpersonal relationships, as well as encouraging the same to subordinates through contact, decision-making and strengthening. They suggested that the ethical leader becoming a good individual has attributes such as dignity, fairness, trustworthiness, accountability, altruism and social motivation.(Sherif et al., 1955) state that judgement on the performance of a leader was judged more efficiently by followers and the 
higher the role of the leader in the organization, demonstrating the likelihood, in general, that one's rank is viewed by followers as 'attractive.' Such attraction was therefore claimed that led to the loyalty of a leader and culminated in the leader's more favorable views.

\subsection{Organizational Fairness Climate}

The organizational environment can be seen as a kind of atmosphere arising from a common understanding of the policies and practices of an organization(Ostroff \& Atwater, 2003). They also indicate that literature has largely ignored the elements responsible to create, shape or contribute to the organization' s climate - particularly those related to the leader's role in informing climate perceptions. From the beginnings of work climate theorizing, academics have claimed that there are several distinct forms of work environment such as service climate, transition, progress, protection and ethics(Schneider \& Snyder, 1975).In this analysis, a particular organizational environment type — ethical environment — and more precisely a sub-set of ethical climate called organizational justice system (Kelloway et al., 1999) will be evaluated as an outcome of ethical leadership. The Department of National Defense 's ethical environment model developed by (Kelloway et al., 1999)includes the organizational environment aspects of responsibility, self-interest, supervisory behavior, co-worker behavior, organizational laws, and organizational justice. Fairness proof is an essential part in assumed professional leadership behavior(Brown \& Treviño, 2006)A previous analysis using the same military organization showed that after all recognized climatic forms were defined and assessed, the organizational environment was the most important to fix. Therefore, since equal treatment of others is both a central ethical responsibility (in most organizations) and a normatively acceptable leadership action, and leaders are supposed to control the actions of their followers, it is predicted that ethical leadership can contribute positively to the organization' s socio-moral environment and act as a key.

Organizational Justice Atmosphere and Followers Job Happiness Organizational climate may be seen as a sort of ecosystem that arises as a consequence of mutual expectations of the policies and procedures of a company (Ostroff et al. 2003). Scholars also concluded that there are several distinct forms of working climates, such as the environment for operation, transition, performance, protection and ethics, from the beginnings of job climate theorization (Schneider 1975; Schneider and Bowen 1985; Schneider et al. 1994, 1996; Zohar 2000; Victor and Cullen 1988). Ostroff et al. (2003) suggest, however, that the ingredients responsible for developing, influencing or contributing to the organizational environment have been largely unexplored in the literature, particularly those related to the position of the leader in informing climate perceptions. In this analysis, one particular form of organizational environment, ethical climate, and more precisely a subset of ethical climate called the climate of organizational justice (Kelloway et al. 1999), will be evaluated as an outcome of ethical leadership. As conceived by Kelloway et al. (1999) for the Department of National Defence, the ethical environment model encompasses the aspects of care, self-interest, supervisory conduct, co-worker behavior, operational rules and organizational justice of the organizational climate. The atmosphere of corporate justice examines the degree to which an institution is equitable in its relations with workers (Fraser 2007). A significant aspect of assumed professional leadership conduct is proof of justice (Den Hartog and De Hoogh 2009; 
Brown et al. 2005). A previous analysis using the same military organization showed that after all the recognized forms of environment were defined and assessed, it was the climate of organizational justice that stuck out as the most important to addressing (Dursun et al. 2004). Therefore, since the equal treatment of others is both a central ethical obligation (in most organizations) and is perceived to be normatively acceptable leadership action at the same time, and leaders are able to affect the behavior of their followers, ethical leadership is expected to relate favorably to the socio-moral environment of the institution and act as a $\mathrm{k}$ Pucic 123 is the ingredient responsible for fostering and preserving the legal environment of the company. This refers to the second assumption.

\section{H1: There is an impact of ethical leadership on organization fairness climate}

\subsection{Career satisfaction}

Contributes to the career growth of the adherent, and is a central element in the understanding and execution of one's self-concept (Super, 1953). This analysis capitalizes on broad sample sizes and data collection in a field environment to delineate the effect of the subordinate' $\mathrm{s}$ rank on expectations in their own. In this analysis, the building of work fulfillment is used to illustrate the reality that career satisfaction is a methodological domain of study in the work partnership, since it employment in a public sector organization, especially the military, is sometimes referred to as a profession rather than a work due to the longer period of the planned jobs, as well as the transformative existence of the institution that promotes the progression of participants across ranks. The principle of social interaction (Blau, 1964) may also be helpful in understanding happiness across mutual interactions during one's career. Specifically, it is the reciprocity with which the leader's attention is traded for the follower's obedience that inevitably results in the follower' $s$ job fulfillment. It is suggested that attention as expressed in the principle of ethical leadership, where leaders listen to what followers have to suggest and keep the better interests of their followers in mind (Brown \& Treviño, 2006).

Sharf (2002) argues that fulfilment with one's job is an essential feature of personal happiness. The definition of work fulfilment is included in this analysis to illustrate the idea that jobs in a public sector organization, especially the military, is sometimes referred to as a career rather than a position because of the prolonged duration of anticipated employment and the evolutionary aspect of the organization that promotes the rise of members through the ranks. The principle of social interaction (Blau 1964) may also be helpful in understanding happiness over the course of one's career by mutual relationships. In particular, it is the reciprocity through which the leader's attention is traded for the follower's obedience that inevitably contributes to the follower's job fulfilment. It is suggested that concern as expressed in the principle of ethical leadership in which leaders listen to what followers have to suggest and have their followers' best interests in mind (Brown et al. 2005) positively impacts respondents' expectations of job fulfilment. Therefore, the third hypothesis in this analysis is that $\mathrm{H} 3$ followers' expectations of ethical leadership are strongly linked to the job satisfaction ratings of followers. Ethical leadership as a mediating tool to date, ethical leadership has been argued to be both a result variable and a context variable. However, the 
issue of whether ethical leadership may relate to beneficial results in the workplace above and beyond those of any prior indicator has scarcely been evaluated in the current literature, in other words, through the propagation of indirect effects (with known exceptions being: Walumbwa and Schaubroeck 2009; Piccolo et al. 2010). The use of the rank of followers in forecasting their own job fulfilment through the mediating power of ethical leadership in the present research, it is argued, would shed new light on the degree to which ethical leadership acts as a way to influence a significant workplace result at one's level in an organization. The foregoing statement is made since, by design, ethical leadership integrates the elements of inclusion, justice and concern in the role modelling process.

\section{H2: There is an impact of ethical leadership on career satisfaction}

\subsection{Affective Commitment}

Many researchers have identified the definition of organizational engagement in a number of ways. (Porter et al., 1974) described organizational loyalty as the confidence and recognition of organizational priorities and principles, the ability to follow organizational objectives, achievements and a clear desire to retain organizational participation. Essentially, it is an individual's affective relationship with his / her Organization is a function of the recognition of corporate principles and the desire to begin operating within the organization. (Hackett et al., 1994) applied to three forms of commitment, namely on-going engagement (continuous engagement), on-going commitment (normative commitment) and on-going affective organizational engagement, which is thoroughly and in the most appropriate manner relative to organizational identity. The meanings of affective interpersonal engagement reinforce the employee's partnership with the organization, representing traits such as recognition of corporate strategies, beliefs and a deep willingness to be identified with the company (Perry, 2004). According to the reports, there are several factors linked to the organization's affective engagement, function and climate. Employment features, enjoyable jobs, job stability, prospects for promotion, growth, organizational support, supervisory support, equal treatment (distributional justice, structured procedural justice, and interactional justice), participatory management, tolerance to innovative concepts, improvement, pay satisfaction, employee engagement, jobs-time discrepancy. (Corbett \& Lee, 2006) Because affective commitment is more important than other forms of commitment, this study explores affective commitment and its association with ethical leadership and ethical environment.

The Meyer and Allen Corporate Dedication Model (1997) claims that an individual who is committed to the company during the economic cycle, works well, retains daily presence and preserves business properties regardless of their engagement with the interests of the organization is a widely recognized definition of what defines a devoted employee. Using this term, organizational loyalty can be seen as a condition of psychological Do as I Tell (and Do) 663123 that defines the relationship of the employee with the organization. Meyer and Allen (1997) validated a three-component organizational engagement model embedded in the philosophy of social interaction (Blau 1964) that tapped the obligation of an employee to stay with the company called normative engagement; reflected the perception of an employee of the potential expense of quitting called continuance engagement; and tapped the feelings of 
psychological attachment of an employee to, in According to March and Simon (1958), the latter is considered a higher order dedication, particularly due to its embedded affective aspect and its capacity to improve employee productivity motivation. In the sense of management analysis, organizational involvement is often a valuable concept since the intensity of the contribution of an employee to an enterprise relates to many outcome variables such as attrition, efficiency, absenteeism, tardiness and OCBB (Meyer et al. 2008). According to Meyer and Allen (1997), evidence indicates that personal satisfaction is the psychological process by which affective engagement evolves. Personal satisfaction is thought to be a necessary building block of one's self-concept, which applies to how people perceive themselves in their specific circumstance (Super 1953). Super (1953) states that the method of creating and applying one's self-concept is one's professional growth itself. Via positive oversight that is equitable and acknowledges employee efforts, ethical leadership can then exert an impact, thereby promoting personal satisfaction and adding to the self-concept of employees.

\section{H3: There is an impact of ethical leadership on affective commitment}

\subsection{Demographic Variables}

\subsubsection{Rank}

Age and experience of persons influence their attitudes, beliefs, and judgments (Lafer, 2014). Various demographic features such as age and gender affect expectations of individuals, the theory of social identity (Ashforth and Mael 1989). Explains how employees can come to describe their occupations the extent of the organizational environment by segregating Self-identifiable groups. This is segregating role serves the function of helping the company to run members to identify and control their social climate

The principle of leadership categorization (Lord et al. 1984) postulates that the opinions of followers decide the success of a chief. Followers base the success expectation of their leader on hierarchically fixed leader prototypes arranged in a diminishing abstraction order. Lower level leaders' goals are considered the most concrete or least abstract. Leadership benefits by being viewed as a leader and the performance of a leader is measured by fulfilling the followers' standards.

As a consequence, low ranking leaders are 'marked the hardest' by their even lower ranking fans, it can be assumed. As the hierarchical hierarchy grows, LCT notes that their leader's follow-up requirements grow less precise and require a greater degree of abstraction, meaning that higher grades will score their own proximal leaders higher than their junior peers. This is also compatible with the observation by Sherif et al. (1955) that high ranks appear to overestimate their decisions solely because of their hierarchical standing. The beauty of this technique is that it approaches leadership from the viewpoint of the opinions of supporters, whether low or high ranking. Leadership is a title bestowed upon the individual by supporters. Leadership is also a psychological phenomenon that is partly clarified by the categorization process (Haslam 2004) and social cognitive theory helps to link the practical recognition of rank with the leadership labelling process. Levine and Butler first 
operationalized the process that explains how expectations are influenced by position or work status (1952). This researchers found that their own performance scores were not related to the successful execution of the assignment, independent of the real performance of a worker on the job, but rather linked to the perceived value of the job. Lower-level workers were rated lower than higher-level staff, even if they performed identically on a given mission. In other terms, the 'halo impact' flowing over from the quality of one's work results in the propensity for raters to score the level of the job and not the person (Levine and Butler 1952; Sherif et al. 1955). Therefore, because the efficacy of ethical leadership depends on open modelling processes such as the demonstration and communication of normatively suitable actions, a comparison may be drawn between leaders conducting mission success in this position (Levine and Butler 1952; Sherif et al. 1955). That is, followers will make decisions about the leader's efficacy/agency in his/her position as an ethical leader and their expectations will be influenced in the organization by their own (lower) rank. Therefore, it is possible that lower ranks in the hierarchy of the workplace would score their proximal leaders lower on a subjective metric such as ethical leadership, and higher ranks in the hierarchy of the workplace would rate their proximal leaders higher with any resultant under- and overestimation in ratings clarified through rank and position differences. Again, this is because the arrangement in this organization between followers and leaders is such that if the follower is smaller, his/her immediate supervisor is often lower in the hierarchy than a follower with a higher supervisor rating.

Pucic (2015) arrived at the same conclusion as Mayer et al. but positively connected the level/rank of the individual in the organization with perceptions of ethical leadership. Mayer et al. and Pucic presented findings related to the vertical structure of the organization and to perceived ethical behaviors that may link ethical leadership and trust levels between employees.

\section{H4: There is a significant positive impact of rank on Career satisfaction}

For workers in higher levels, the partnership between consideration leadership and affective organizational engagement is more successful in the consideration leadership. Organizational job interactions have also been internalized in higher levels and may therefore be less preferred and therefore less successful in increasing their affective devotion.

\section{H5: There is a significant positive impact of rank on Affective commitment}

Organizational justice centers on workers as the focal stakeholder finds the supply chain background to be a fair benefit standard, fair salary or fair price and how such a fair atmosphere takes shape in which sales take place.

\section{H6: There is a significant positive impact of rank on Organization fairness climate}

The notion of beauty can be interpreted as a feature of the role of a leader in the concept of ethical leadership which requires the additional aspects of caring, empathy and equal consideration of followers. (2006 by Brown and Treviño).

H7: There is a significant positive impact of rank on Ethical Leadership 


\subsubsection{Age}

As we grow older, work satisfaction continues to increase but often tends to decline the longer we remain in a single job. Previous study has shown that workplace satisfaction continues to improve as workers mature and receive greater wages and benefits.

\section{H8: There is a significant positive impact of age on Career satisfaction}

Affective dedication was correlated more closely with age than with tenure. Allen and Meyer (1993) say that it is not just improved interactions for older employees that contribute to enhanced participation, but also potential cohort results.

\section{H9: There is a significant positive impact of age on Affective commitment}

Age has been found to be related to variety of job attitudes like job satisfaction, job Involvement organizational commitment and turnover (Rhodes 1983).

\section{H10: There is a significant positive impact of age on Organization fairness climate}

It is quite obvious that as a man attain maturity there is automatic generate Ethics in his deeds, way of behaving and meanwhile he/she realizes the attributes of their followers as well.

\section{H11: There is a significant positive impact of age on Ethical Leadership}

\subsubsection{Education}

Education is one and the most important factor of all those factors influencing career satisfaction. It is helpful in understanding happiness across mutual interactions during one's career. Specifically, it is the reciprocity with which the leader's attention is traded for the follower's obedience that inevitably results in the follower' s job fulfillment (Campion \& Wang, 2019).

\section{H12: There is a significant positive impact of education on Career satisfaction.}

Commitment of an employee plays an important role in reducing employee turnover, increase working relations and increasing organization' s performance. It can be affected by many other factors but what impact we have discussed is that education has its effect on and affective commitment. It was suggested by the Meyer and Allen's model that enhances the mechanism of personal accomplishment in followers through education which in turn generates the feelings of connections, involvement, and recognition with the organization.

\section{H13: There is a significant positive impact of education on Affective commitment.}

This means that if importance of education is promoted within the organization then there will be good organization' $s$ fairness climate. There will be a climate that will emerge as a result of shared perceptions of an organization's policies and procedures (Kanungo, 1996).

H14: There is a significant positive impact of education on Organization fairness climate.

It was suggested by the (Meyer and Allen' s) model that enhances the mechanism of personal accomplishment in followers through education which in turn generates the feelings of 
connections, involvement, and recognition with the organization.

H15: There is a significant positive impact of education on Ethical leadership.

\subsubsection{Working Hours}

The findings suggest that, in general, high working hours and overtime do not contribute to reduced satisfaction. Instead, growing working hours and overtime have a beneficial effect on life and job satisfaction, while a detrimental impact on satisfaction is the urge to reduce working hours. (Sarah Holly, Mohnen of Alwine (2012)

\section{H16: There is a significant positive impact of working hours on Career satisfaction}

Terera \& Ngirande conducted a research on and stated that working hours is positivley influenced by affective commitment. If we increase working hours, affective commitment will automatically be increased. According to Khan et al. (2011), affective commitment is greatly inflenced by two important factors and one of them is working hours Thus working hours plays an inevitable role in increasing affective commitment of an employee.

\section{H17: There is a significant positive impact of working hours on Affective commitment.}

Hackman, et al. (2014), explored the relationship between different components of working hours with Organization fairness climate results in increase in the level of organization fairness climate where an employee finds it' $s$ himself working in a pleasant and fair working environment, and showed a positive affect

\section{H18: There is a significant positive impact of working hours on Organization fairness climate.}

Job Satisfaction is the feeling of pleasure or excitement that an employee experience and wants within the limited working hours. This feeling can come from job content, workload, compensation and growth opportunities.

\section{H19: There is a significant positive impact of working hours on Ethical Leadership}

\subsubsection{Individualism}

Individualism is a reflection of how significant community people put on their own beliefs and health. In a strongly individualistic society, members put considerable emphasis on themselves or a select group of peers.(Smith \& Hume, 2005). Many Individual are heavily regulated internally, stressing private objectives, giving attention to what the person does rather than who the person is. And where one sees more disconnected and rootless persons, where citizens believe individual decisions are stronger than collective decisions. Where one's path is appropriate, where one's own happiness is valued, where friendship is a question of personal preference (Triandis et al., 1988). Several studies have supported individualism-collectivism as the major dimension of cultural variability that affects conflict communication styles (Chua \& Gudykunst, 1987). To conclude, representatives of individualistic cultures prefer to use confrontation-approach communication styles, contributing to the use of dominant style or solution-oriented form (integrating and 
compromising) in conflict management. These models stress self-concern for others' face-concern. On the other hand, members of collectivistic cultures prefer to use passive obliging form or resist conflict management style. This is attributed to the desire for the other person's "face-saving" and "face-giving" wishes in the confrontation scenario (Ting-Toomey, 1988).

Thus organization design their working environment in a way that not only increases the culture of individualism which will result in employee career satisfaction. And when employee is happy and satisfied it ultimatley benefits company (Colin W. Evers, 2013).

\section{H20: There is a positive impact of individualism on Career satisfaction}

The more the culture of individualism in an organization the more an employee is likely to remain associated with the organization. Employees' satisfaction with their jobs and their willingness to remain in an organization is always debatable. Employee with low career commitment will only do enough work to stay in the organization without any dedication (JOHN A WAGNER III, 1995).

\section{H21: There is a positive Impact of individualism on Affective commitment}

Companies in order to retain their motivated and skilled employees, rely on offering them fair ptactices at workplace. Success of any organization lies in formulating best strategies and plan in order to retain \& motivate its employees (Nada Korac-Kakabadse, 2002).

\section{H22: There is an impact of individualism on Organization fairness climate}

The organization design their working environment in a way that not only increases the culture of individualism which will result in employee career satisfaction. And when employee is happy and satisfied it ultimatley benefits company (Colin W. Evers, 2013).

\section{H23: There is an impact of individualism on Ethical Leadership}

\subsubsection{Tenure}

Wright and Bonett (2002) suggest that the impact of tenure in the relationship between affective organizational involvement and job results are especially relevant to investigate because higher tenure is likely to be positively linked to both engagement and performance, thereby inflating or generating a false association between engagement and performance.

\section{H24: There is an impact of Tenure on Affective commitment}

The degree and tenure to which an entity is equal in its relations with employees is discussed by the organizational fairness environment (Fraser 2007)

\section{H25: There is an impact of Tenure on Organization fairness climate}

The impact of ageing on work satisfaction, as White and Spector (1987) say, are indirect, by other variables. This indicates, among other factors, that not only because they get most of what they expect out of jobs (i.e., improved feelings of power, better pay, higher level), but also because of their longer experience, older employees are more fulfilled. 


\section{H26: There is an impact of Tenure on Career satisfaction}

(Sherif et al., 1955) state that judgement on the performance of a leader was judged more efficiently by followers and the higher the role of the leader in the organization and work duration with subordinates shows the efficiency of leader.

\section{H27: There is an impact of Tenure on ethical leadership}

\subsubsection{Spirituality:}

Spirituality is a spiritual search for finding the answers to the fundamental questions of existence, purpose and connation with the divine or transcendent that can (or may not) contribute to the creation of religious rites and the forming of society (Tanyi, 2002). According to Fry (2003), spirituality involves two basic elements through a person's life: (a) self-transcendence, manifesting in a sense of mission or fate, and (b) conviction that one's job has significance and importance beyond economic rewards or self-gratification. A feeling of purpose and a greater significance fosters those ideals, like vision. Another study (M. P. Kriger \& Hanson, 1999) suggested a common collection of moral values - honesty / truthfulness, faith, modesty, grace, love, loyalty, service, and stillness / peace - essential to allow moral principles to flourish and develop in modern organizations. Another spirituality concept in leadership is the expansion of (Gordon \& Yukl, 2004) Multiple Association Paradigm by (M. Kriger \& Seng, 2005) Kriger and Seng concluded that faith affects leadership principles; that reduces the impact of leadership vision on leadership behavior; that in turn affects the degree of subordinate dedication to leadership mission and goals; that ultimately affects leadership performance as measured by business benefit, ideals and mission fulfilment, and mutual organizational gain for society and key stakeholders.

\subsection{7(i) Beliefs}

Recently it have seen that many authors have addressed that leaders personal beliefs are mostly reflected in their leadership style which is not a good thing but it might create lot of problems for the followers (Lewicki, et.al, 2001). Many leadership theories have proclaimed that the beliefs and values of a leader may have impact their followers and organization. Some authors for example Avolio and Gardner (2005) and Gardner et al. (2005) argued in support of this influence and declared that this impact may result in improved performance. While some of the authors strived to find the difference between "moral person" and " moral manager". Moral person is describes as the individual traits, beliefs, values and character of a leader whereas moral leader is one who strives to have influence on his moral and immoral behavior of his followers (Dent, 2005).

\section{H28: There is a positive impact of Spirituality Believe on ethical leadership.}

People having belief in God accept each. It helps in understanding the extent to which one is happy with their job hence an employee' s willingness to perform at an optimum level" . According to Armstrong (2006), it is positive and motivated attitude towards ones job. Spirituality Believe and career satisfaction are positively correlated with each other. The strong the Spirituality Believe the more employees will be satisfied from their career. When 
an employee is satisfied that individual shows willingness to work wholeheartedly for the growth and productivity of the organization and for that he/ she uses all his abilities, skills and available resources to achieve the organizational goals Osibanjo et.al (2015),

\section{H29: There is a positive impact of Spirituality Believe on Career satisfaction}

People are committed to their organizations in response to the way they perceive their organizations in light of workplace spirituality. If the spiritual beliefs of leader increases then employee will feel, attached, valued and involved with the organization it helps understanding the level of commitment of an employee.

\section{H30: There is a positive impact of Spirituality Believe on Affective Commitment}

Spirituality proved to be a strong predictor of several positive organizational outcomes (Evers \& Lakomski, 2013.

\section{H31: There is a positive impact of Spirituality Believe on Organization fairness climate}

\subsection{7(ii) Coping}

Studies have recommended that ethics' perception are linked with the leaderships' perception. There are number of searches which advocate integrity's importance for the success of leadership (Korac-Kakabadse, 2002). Leader being Spiritual has divine power and has capability to lead the team (Sean J. Gehrke, 2008).

\section{H32: There is a positive impact of Spirituality coping on ethical leadership}

Religiosity had a strong direct impact on their overall job satisfaction (Sean J. Gehrke, 2008).

\section{H33: There is a positive impact of Spirituality coping on Career satisfaction}

Spiritual person has a fear of God and moral Ethics he never depart from organization in difficult time. There is a positive impact of Spirituality coping on Organization fairness climate. This means that if the ratings of followers for the Spirituality coping of their leader increases then there will also an increase in fairness climate of organization (John Pucic, 2015).

\section{H34: There is a positive impact of Spirituality coping on Affective commitment}

Roberson (2006) found that members having the immense power of spiritual quality never disappoint the leader and keep follow the clear rules and regulation to maintain the peace environment in organization, As a result, this collective sense-making process leads to the convergence of justice perceptions within the work unit

\section{H35: There is a positive impact of Spirituality Believe on Organization fairness climate}

\subsection{7(iii) Practice:}

Results indicate that spiritual leadership was positively linked to employee job efficiency, information sharing activity and creativity behavior, when we accounted for potential confusing effects of moral leadership and benevolent leadership, and ruled out alternate 
theories of ethical leadership (Phipps, 2012)

\section{H36: There is a positive impact of Spirituality Practices on ethical leadership}

Several studies have also revealed the positive correlation between job satisfaction and lower turnover (Judge et al. 2017). The hypothesis of ' a happy worker is a productive worker' is still believed by many in the industry

\section{H37: There is a positive impact of Spirituality Practices on Career}

Workplace spirituality has implications for employee affective commitment among, as lost with the alienation that is triggered by the dehumanized practices (Campion \& Wang, 2019).

\section{H38: There is a positive impact of Spirituality Practices on Affective commitment}

(Walumbwa and Schaubroeck 2009; Piccolo et al. 2010) supported the idea that spirituality practices seems to enhance fairness climate in organization.

H39: There is a positive impact of Spirituality Practices on Organization fairness climate

\subsection{7(iv) Experience:}

The leaders' spiritual experiences not only influence followers' satisfaction and motivation at work but it also results in ethical impact on followers (Gehrke, S. J., 2008). Leaders have foremost influence on ethics and behaviors of their followers, these studies reported leaders this influence on followers are primary one while their influence on the ethical behaviors of their peers was reported as secondary influence (Phipps, K. A., 2012).

Embodiment of spiritual values such as integrity, and in the demonstration of spiritual behavior such as expressing caring and concern, leaders have foremost influence on ethics and behaviors of their followers. Studies reported that leaders this influence on followers are primary one while their influence on the ethical behaviors of their peers was reported as secondary influence (Phipps, K. A., 2012).

\section{H40: There is a positive impact of Spirituality experiences on ethical leadership}

The leaders' spiritual experiences not only influence followers' career satisfaction and motivation at work but it also results in ethical impact on followers (Gehrke, S. J., 2008).

H41: There is a positive impact of Spirituality experiences on Career satisfaction

Promoting the spirituality of the workplace continues to boost the engagement and corporate efficiency of workers, as long as this is achieved in the sense of reverence for human integrity (Kelly A. Phipps, 2011).

\section{H42: There is a positive impact of Spirituality experiences on Affective commitment}

A person being Spiritual wants fairness and equity in organizational environment around himself. According to Parks (2000) Spirituality experiences is referred as way of making meaningful attempt in fully understanding the human experience. 
H43: There is a positive impact of Spirituality experiences on Organization fairness climate

\section{Methodology}

\subsection{Sample Size}

The sample size of the study will be according to the base research paper. The base research paper has collected the data of 1274 respondents. Hence this research is also collecting data from 500 respondents.

\subsection{Sampling Technique}

The current study has aimed to use purposive sampling for data collection. The reasons for using purposive sampling were that it allowed the researcher to gather knowledge via certain experts from the specific targeted population or domain. It also helped in directly communicating to the participants and generates required knowledge and results regarding research objective. This research collected data from 300 respondents.

\subsection{Instrument}

The questionnaire consisted of two basic parts, demographics which were followed by the main constructs of Ethical Leadership, Organizational Fairness Climate, Career Satisfaction, Affective Commitment, Individualism, Spiritual Experiences, and Spiritual Coping. The first part of the instrument consisted six basic questions, and the second phase had 39 items for Leadership, Organizational Fairness Climate, Career Satisfaction, Affective Commitment, Individualism, Spiritual Experiences, and Spiritual Coping. These statements were measured on five-point Likert scale according to the importance of the individual respondents in which 1 represented "strongly disagree" to 5 " strongly agree" (Saunders et al., 2009). The items which are used to examine the constructs are based on literature review and have been validated in previous studies.

Variable wise classification with respect to questionnaire are given below

Ethical Leadership: In the present study, Ethical Leadership questionnaire consist of 10 items adopted from (Brown, M. E., Treviño, L. K., \& Harrison, D. A. (2005).

Organizational Fairness Climate: In the present study, Organizational Fairness Climate questionnaire consist of 5 items adopted from (Kelloway, E. K., Barling, J., Harvey, S., \& Adams-Roy, J.E. (1999)

Career Satisfaction In the present study, Career Satisfaction questionnaire consist of 7 items adopted from Warr, P. B., Cook, J. D., \& Wall, T. D. (1979)

Affective Commitment: In the present study, Affective Commitment questionnaire consist of 5 items adopted from Meyer, J. P., \& Allen, N. J. (1997).)

Individualism: In the present study, Individualism questionnaire consist of 5 items in which 


\section{Macrothink}

International Journal of Human Resource Studies

ISSN 2162-3058

2021, Vol. 11, No. 1

item no 1, 24 \& 5 adopted from Wagner and Moch (1986), however item no 3 adopted from Erez and Earley (1987).

Spirituality: In the present study, Spirituality is further divide into 4 sub category (Belief, Experience, Coping, Practices) and questionnaire consist of 12 items adopted from Fetzer Institute (1999).

\subsection{Demographic Profile}

For this study, primary data was used which was collected through online and physical survey. Survey form was sent to 500 respondents. The below demographics of respondents.

Table 1.

\begin{tabular}{|l|l|l|}
\hline Valid Survey Cases & Number & Percentage \\
\hline Gender & & \\
\hline Male & 425 & $85 \%$ \\
Female & 75 & $15 \%$ \\
\hline Age & & \\
\hline 21 - 30 & 213 & $42.6 \%$ \\
31 - 40 & 150 & $30 \%$ \\
41 - 50 & 90 & $18 \%$ \\
51 - 60 & 47 & $9.4 \%$ \\
\hline Education & & \\
\hline Under-Graduation & 75 & $15 \%$ \\
Graduation & 230 & $46 \%$ \\
Post-Graduation & 180 & $36 \%$ \\
Masters of Philosophy & 20 & $4 \%$ \\
Doctor of Philosophy & 5 & $1 \%$ \\
\hline Designation & & \\
\hline Officer & 250 & $50 \%$ \\
Senior Officer & 125 & $25 \%$ \\
Manager & 90 & $18 \%$ \\
Senior Manager & 20 & $4 \%$ \\
Executives & 15 & $3 \%$ \\
\hline Tenure & & \\
\hline 01 - 10 Years & 290 & $58 \%$ \\
11 - 20 Years & 150 & $30 \%$ \\
21 - 30 Years & 45 & $9 \%$ \\
31 Plus & 15 & $10 \%$ \\
\hline Working Hours & 280 & $05 \%$ \\
\hline 8 AM to 5 PM & 50 & \\
9 AM to 6 PM & 25 & $56 \%$ \\
1PM to 9 PM & & \\
8 PM to 5 AM & & \\
\hline
\end{tabular}


In the above displayed table, the respondent' $\mathrm{s}$ demographic profile is mentioned. It provides an idea regarding the kind of population that has been the participants. The respondent' $\mathrm{s}$ profiles show that majority of the population are males with around 95\% male and 5\% females. Hence, we can also evaluate that the Islamic financing has majority of males. Respondents were of different age groups, ranging from 21 years of age till 60 years. Table shows that most of the respondents were young ranging between 21 and 30. $42.6 \%$ of the respondents were in age bracket of 21-30 which is a huge number; a very good percentage. $30 \%$ were in age bracket of 31-40. 18\% consisted of age bracket $41-50$ and rest $9.4 \%$ belonged to 51-60. Qualification of respondents ranged from graduate to doctor of philosophy. Statistics shows that percentage of graduated respondents is $46 \%$ which covers the greatest part. 36\% is of Master level and 4\% consists of Master of Philosophy and the rest $1 \%$ has Doctor of Philosophy. Next statistics shows different designations of respondents ranging from officer to executives. Majority of the respondents in this study were officers and covered $50 \%$ of the sample size. Similarly $25 \%$ belonged to Senior Officer level positions, $18 \%$ were managers, and 3\% were executives. Employment tenure was also covered in demographic section. This included respondents with 1 to 10 years of experience, then 11 to 20 years, 21 to 30 years and lastly 31 plus. Percentiles of respondents varied and 58\% possessed 1 to 10 years of experience, $30 \%$ fell in the category of 11 to 20 years' experience, $9 \%$ fell in the category of it was 32 to 30 years' experience and lastly only 5\% respondents possessed more than 31 years of experience. Demographics also included working shifts of the respondents. Four shifts were taken into account for the research purpose. One was $8 \mathrm{AM}$ to $5 \mathrm{PM}$ shift, then $9 \mathrm{AM}$ to $6 \mathrm{PM}$ shift, $1 \mathrm{PM}$ to $9 \mathrm{PM}$ shift and last one was $8 \mathrm{PM}$ to $5 \mathrm{AM}$. Majority of the respondents work from 9AM to 6PM, their percentage is 56\%, 29\% work from 8 AM to $5 \mathrm{PM}$ and only 5\% work from 8PM to 5AM.

\section{Results}

\subsection{Descriptive Statistic}

Descriptive analysis is completed to grasp comprehensive gain from statistics. It is used to identify the strength of relationships between all variable.

A detail descriptive Statistics of table 2 is given in appendix.

\subsection{Structural Equation Modeling}

We used the structural equation model (SEM) for evaluating the study hypothesis, while work has been carried out using Smart PLS. In addition, the subtle and actual results of all the test prototypes have been analyzed. The usage of the structural equation model (SEM) was found to be the most sophisticated technique utilized below various regression models and techniques (Barron \& Kenny, 1986). It was used to determine the structural interaction between exogenous and endogenous variables. This involves factor analysis and multivariate analysis. In comparison, the regression equation targets to describe each build to determine the cause and effect relationship, whereas all the variables in the causal process should show their cause and effect at the exact moment. Similarly, the principle of utilizing this model guarantees the use of a bootstrapping strategy known to be appropriate for both small and 


\section{Macrothink}

International Journal of Human Resource Studies ISSN 2162-3058 2021, Vol. 11, No. 1

broad sample sizes and does not involve some sort of indirect effect (Hayes, 2013). In order to verify both direct and indirect results, a method known as bootstrapping has been applied (Shrout \& Bolger, 2002).

\subsection{Measurement of Outer Model}

Our aim is to determine the fit in the measurement model and to verify its durability and validity. We conduct a programme naming Smart PLS test for convergent meaning and distinguishing validity.

\subsubsection{Factor Loadings Significant}

The Table also contains loadings used for (CFA) confirmatory factor analysis. Descriptive statistics Construction for loading 0.5 are considered to be high loading variables, whereas structures below 0.5 are considered to be less excluded from the table.

\subsubsection{Convergent Validity}

The degree of consensus is convergent in at least two measurements of a related structure (Carmines and Zeller, 1979). Validity convergence was tested by inspection of the variance derived from each factor (Fornell and Larcker, 1981). If the meaning derived by the differential reaches 0.5 then convergent validity is defined and it is assumed that loads are fine but less than 0.5 is deemed less successful for the analysis.

Following table displays the result.

\begin{tabular}{|c|c|c|c|c|c|c|}
\hline Constructs & Items & Loadings & $\begin{array}{l}\text { Composite } \\
\text { Reliability } \\
\end{array}$ & $\begin{array}{l}\text { Cronbach's } \\
\text { Alpha }\end{array}$ & rho_A & AVE \\
\hline TENOUR & TN & 1.000 & 1.000 & 1.000 & 1.000 & 1.000 \\
\hline \multirow{3}{*}{$\begin{array}{l}\text { Affective } \\
\text { Commitment }\end{array}$} & AC 1 & 0.819 & \multirow[b]{3}{*}{0.701} & \multirow[b]{3}{*}{0.567} & \multirow[b]{3}{*}{0.663} & \multirow[b]{3}{*}{0.353} \\
\hline & $\mathrm{AC} 2$ & 0.651 & & & & \\
\hline & AC 3 & 0.711 & & & & \\
\hline Age & AGE & 1.000 & 1.000 & 1.000 & 1.000 & 1.000 \\
\hline \multirow[b]{3}{*}{ Career Satisfaction } & CS 1 & 0.704 & \multirow[b]{3}{*}{0.860} & \multirow[b]{3}{*}{0.809} & \multirow[b]{3}{*}{0.812} & \multirow[b]{3}{*}{0.468} \\
\hline & CS 2 & 0.736 & & & & \\
\hline & CS 3 & 0.755 & & & & \\
\hline Education & EDU & 1.000 & 1.000 & 1.000 & 1.000 & 1.000 \\
\hline \multirow[b]{3}{*}{ Ethical Leadership } & EL 1 & 0.743 & \multirow[b]{3}{*}{0.912} & \multirow[b]{3}{*}{0.893} & \multirow[b]{3}{*}{0.900} & \multirow[b]{3}{*}{0.511} \\
\hline & EL 2 & 0.820 & & & & \\
\hline & EL 3 & 0.772 & & & & \\
\hline \multirow[b]{2}{*}{ Individualism } & $\begin{array}{l}\text { IND } \\
1 \\
\end{array}$ & 0.791 & \multirow[b]{2}{*}{0.731} & \multirow[b]{2}{*}{0.583} & \multirow[b]{2}{*}{0.676} & \multirow[b]{2}{*}{0.384} \\
\hline & $\begin{array}{l}\text { IND } \\
2\end{array}$ & 0.790 & & & & \\
\hline \multirow{3}{*}{$\begin{array}{l}\text { Organizational } \\
\text { Fairness Climate }\end{array}$} & OF 1 & 0.793 & \multirow[b]{3}{*}{0.869} & \multirow[b]{3}{*}{0.816} & \multirow[b]{3}{*}{0.845} & \multirow[b]{3}{*}{0.572} \\
\hline & OF 2 & 0.843 & & & & \\
\hline & OF 3 & 0.774 & & & & \\
\hline
\end{tabular}




\begin{tabular}{|c|c|c|c|c|c|c|}
\hline Position & PSO & 1.000 & 1.000 & 1.000 & 1.000 & 1.000 \\
\hline \multirow[b]{2}{*}{ Spiritual Believe } & SB 1 & 0.992 & \multirow[b]{2}{*}{0.661} & \multirow[b]{2}{*}{0.624} & \multirow[b]{2}{*}{-3.871} & \multirow[b]{2}{*}{0.548} \\
\hline & SB 2 & 0.336 & & & & \\
\hline \multirow[b]{2}{*}{ Spiritual Coping } & SC 1 & 0.853 & \multirow[b]{2}{*}{0.780} & \multirow[b]{2}{*}{0.654} & \multirow[b]{2}{*}{0.784} & \multirow[b]{2}{*}{0.482} \\
\hline & SC 2 & 0.800 & & & & \\
\hline \multirow{3}{*}{$\begin{array}{l}\text { Spiritual } \\
\text { Experience }\end{array}$} & SE 1 & 0.623 & \multirow[b]{3}{*}{0.850} & \multirow[b]{3}{*}{0.781} & \multirow[b]{3}{*}{0.827} & \multirow[b]{3}{*}{0.659} \\
\hline & SE 2 & 0.908 & & & & \\
\hline & SE 3 & 0.874 & & & & \\
\hline \multirow[b]{2}{*}{ Spiritual Practices } & SP 1 & 0.784 & \multirow[b]{2}{*}{0.582} & \multirow[b]{2}{*}{0.606} & \multirow[b]{2}{*}{-0.483} & \multirow[b]{2}{*}{0.362} \\
\hline & SP 3 & 0.661 & & & & \\
\hline Working Hour & WH & 1.000 & 1.000 & 1.000 & 1.000 & 1.000 \\
\hline
\end{tabular}

Reflective Model assessment is done through various indicators and test. The very first assessment is to evaluate loadings of indicators (Hair et al., 2019). It is recommended that the value of loadings should be above 0.078 as it will tell that the variables explains more than $50 \%$ variance of indicators (Freeze, n.d.). Thus if the value is greater than 0.078 item is considered as reliable. In above table most of the items are considered as reliable.

\subsubsection{Composite Reliability}

Composite Reliability also knows as construct Reliability is a measure of scale reliability or it measures the reliability of constructs' items (Mason \& Perreault, 1991). The acceptable range for composite reliability is suggested to be between 0.70 and 0.95 (Diamantopoulos et al., 2012; Drolet and Morrison, 2001). Above table shows that items having value between 0.60 and 0.70 are acceptable. Similarly items having values 0.70 and 0.90 range from " satisfactory to good. Lastly, all those items having values of 0.95 or greater are not reliable or problematic.

\subsubsection{Cronbach Alpha}

Cronbach Alpha is also used to measure internal consistency reliability just like composite reliability (Alarcón \& Sánchez, n.d.). Both are measure of scale reliability but Cronbach Alpha generates lower values than construct reliability. Also Cronbach Alpha is not a very precise measure of scale reliability since the items are not adjusted or un-weighted. While composite reliability weights the items and these weighted items are based on loading of every individual indicator. (Hair et al., 2019). Thus composite reliability is higher than Cronbach Alpha. Above table indicates that Affective Commitment, Individualism, Spiritual Believe, Spiritual Coping and Spiritual Practices have lower reliability values then the acceptable range which is 0.70 to 0.95 .

\subsubsection{Rho_A}

Rho_A is considered as almost exact measure of scale reliability and that is because it lies between composite reliability and Cronbach (Hair et al., 2019). As composite reliability is considered as too linnet while Cronbach Alpha is conservative and usually scale reliability is observed between these two extreme values (Freeze, n.d.).Therefore Rho_A may considered as good measure for reliability. It is recommended that the value of Rho_A should be higher 
than 0.70 (Cunningham et al., 2001). In above table Rho-A values of Affective Commitment, Individualism, Spiritual Believe, Spiritual Coping and Spiritual Practices is less than 0.70 which tells that these constructs are not reliable items, rest are reliable.

\subsubsection{Average Variance Extracted (AVE)}

Average Variance Extracted (AVE) is a measure of convergent validity. Convergent validity can be explained as degree to which construct is well defined by its items (Cheah et al., 2018). AVE captures the level of variance in indicators of construct. Acceptable threshold for AVE is 0.5 (Alarcón \& Sánchez, n.d.). From the table it can be concluded that Affective Commitment, Career Satisfaction, Individualism, Spiritual Coping and Spiritual Practices have lower values than acceptable threshold and thus are not reliable.

\subsubsection{Discriminant Validity}

Table 4

\begin{tabular}{|c|c|c|c|c|c|c|c|c|c|c|c|c|c|c|}
\hline \multicolumn{15}{|l|}{ Fornell-Larcker Criterion } \\
\hline & TENOUR & $A C$ & AGE & CS & EDU & EL & IND & OF & POS & SB & SC & SE & $S P$ & WH \\
\hline TENOUR & 1.000 & & & & & & & & & & & & & \\
\hline affective commitment_ & 0.050 & 0.594 & & & & & & & & & & & & \\
\hline age_ & 0.294 & -0.080 & 1.000 & & & & & & & & & & & \\
\hline career satisfaction_ & 0.017 & 0.450 & -0.014 & 0.684 & & & & & & & & & & \\
\hline education_ & 0.112 & 0.293 & 0.002 & 0.055 & 1.000 & & & & & & & & & \\
\hline ethical leadership_. & 0.004 & 0.349 & 0.031 & 0.451 & 0.278 & 0.715 & & & & & & & & \\
\hline individualism_ & -0.103 & 0.388 & -0.078 & 0.398 & 0.178 & 0.341 & 0.620 & & & & & & & \\
\hline organisational fairness climate_ & 0.114 & 0.385 & 0.016 & 0.547 & 0.176 & 0.510 & 0.324 & 0.756 & & & & & & \\
\hline position_ & 0.352 & 0.047 & 0.173 & -0.086 & 0.263 & 0.212 & 0.101 & 0.120 & 1.000 & & & & & \\
\hline spritual believe_ & 0.125 & 0.167 & 0.058 & -0.047 & 0.008 & 0.050 & 0.007 & 0.081 & -0.005 & 0.740 & & & & \\
\hline spritual coping_ & -0.220 & 0.025 & -0.205 & 0.136 & -0.106 & -0.094 & 0.321 & 0.020 & -0.070 & -0.049 & 0.694 & & & \\
\hline spritual experience_ & -0.051 & -0.038 & -0.026 & -0.006 & -0.101 & -0.204 & -0.041 & -0.053 & -0.138 & 0.257 & 0.453 & 0.812 & & \\
\hline spritual practices_ & -0.067 & 0.052 & -0.018 & -0.116 & -0.115 & -0.089 & 0.152 & -0.033 & -0.102 & 0.099 & 0.378 & 0.318 & 0.602 & \\
\hline working hour_ & 0.451 & -0.031 & 0.256 & -0.082 & 0.061 & 0.042 & -0.020 & -0.022 & 0.283 & 0.122 & -0.232 & -0.106 & -0.059 & 1.000 \\
\hline
\end{tabular}

Discriminant validity measures the construct which should not be related is actually unrelated or not. In other words it is the test of variables which are unrelated to each other in the research, (Najmi \& Ahmed, 2017). Discriminant validity is measured by Fornell and Larcker Criterion and heterotrait-monotrait (HTMT). Threshold value to measure discriminant validity in which the variable is considered to be independent from the other variable must be higher than 0.1(Henseler et al., 2015). We used Fornell and Larcker Criterion to measure discriminant validity. Table indicates that all the values are greater than 0.1 which means that the construct which was not supposed to be related are actually not related.

\subsubsection{Model Fit Measure}

Table 5

\begin{tabular}{|c|c|c|}
\hline \multicolumn{3}{|c|}{ Fit Summary } \\
\hline & Saturated Model & Estimated Model \\
\hline SRMR & 0.081 & 0.086 \\
\hline
\end{tabular}




\begin{tabular}{|l|l|l|} 
d_ULS & 8.078 & 9.041 \\
\hline d_G & 2.270 & 2.334 \\
\hline Chi-Square & 3382.903 & 3447.872 \\
\hline NFI & 0.508 & 0.498 \\
\hline
\end{tabular}

Model Fit measure refers to the degree to which the particular model fits the theoretical data (Kaplan, 2000). Since there is no direct evaluation of model is available in structural equation modeling therefore different criterions are taken into consideration to measure model fit (Bentler and Bonett, 1980). Discriminant validity can be measured by different criterions such as standardised root-mean-square residual (SRMR), and the exact model fits like d_ULS and d_G, Normed Fit Index (NFI), and $\chi^{2}$ (Chi-square). Proposed threshold value for SRMR is less than 0.08 while NFI should be higher than 0.09 (Kaplan, 2000). Similarly d_ULS and d_G are recommended not to have value more than upper bounds $95 \%$ and $99 \%$ (cf. Hoyle \& Panter, 1995).

\subsubsection{Regression}

Table 5

\begin{tabular}{|l|l|l|}
\hline Variables & R Square & $\begin{array}{l}\text { R Square } \\
\text { Adjusted }\end{array}$ \\
\hline affective commitment_ & 0.284 & 0.257 \\
\hline career satisfaction__ & 0.389 & 0.366 \\
\hline ethical leadership___fairness & 0.229 & 0.202 \\
\hline $\begin{array}{l}\text { organizational } \\
\text { climate_ }\end{array}$ & 0.320 & 0.294 \\
\hline
\end{tabular}

Regression analysis is the tool method used to find out the relationship between dependent and independent variable(s) (Mason \& Perreault, 1991). Above table shows the result of regression. Table shows the value of $\mathrm{R}^{2}$ which coefficient of determination. It measures the amount of variance in dependent variable. (Shmueli and Koppius, 2011). If the value of $\mathrm{R}^{2}$ is $0.75,0.50$ and 0.25 this means that variable is substantial, moderate and weak respectively (Henseler et al., 2009; Hair et al., 2011). Table shows that affective commitment and ethical leadership have weak relationship. $\mathrm{R}^{2}$ value of Affective commitment and ethical leadership is $0.257 \& 0.202$ respectively which means that these variables are $25 \%$ and $20 \%$ fit the regression model. On the other hand, career satisfaction and organizational fairness climate show moderate relationship. Their $\mathrm{R}^{2}$ value is $0.366 \& 0.294$ respectively which means that these variables are $36 \%$ and $29 \%$ fit the regression model.

\subsection{The Structural Model (Inner Model) and Hypotheses Testing}

The structural model is very useful method for understanding and evaluating the complex relations of the constructs. To understand the relationship of variables, structural model was run on SmartPLS 3.2.3 through bootstrapping. Graphical representation of the model is attached along with the interpretation. Evaluation of structural model is based on convergent 
validity, collinearity, statistical significance, and reliability of the indicator weights (Hair et al., 2017a). Below table tests hypotheses of the study. It tell about the relationship of one variable with the other. The table shows that there is no impact of age on affective commitment, organizational fairness climate, career satisfaction and ethical leadership as the $t$ value of all these variables is less than 2; the acceptable $t$ threshold of $t$ value is -2 or +2 . Similarly if we look at the $\mathrm{P}$ value of age with all these variables is greater than 0.05 . Hypothesis is only acceptable if the $\mathrm{P}$ value is less than 0.05 . Therefor all these hypotheses (H1 to H4) are rejected. Moving further analyzing the relationship between education and affective commitment, it can be seen that education has positive impact on affective commitment. Because the t-value of education and affective commitment is 3.538 which is greater than +2 and $\mathrm{P}$ value is also less than 0.05 . Therefore, "H5: There is an impact of education on Affective commitment" is true. Or in other words it can also be said that education helps in individual's affective relationship with his / her Organization is a function of the recognition of corporate principles and the desire to begin operating within the organization. Similarly education has positive impact on ethical leadership as the as the $t$ value is 3.312 and the $\mathrm{p}$ value is 0.001 which is again less than 0.005 . But education has no impact on career satisfaction and organizational fairness climate as it can be seen that their $t$ value is less than 2 and p value is also greater than 0.05 . Therefore hypotheses H6 \& H7 are rejected. Ethical leadership and individualism has positive impact on affective commitment, organizational fairness climate, career satisfaction and ethical leadership. Hence hypotheses $\mathrm{H} 9$ to $\mathrm{H} 15$ are accepted as the p value is less than 0.05 . Hypotheses H16 \& H17 are rejected because their $\mathrm{p}$ value is greater than 0.05 . It can be said that position has no impact on affective commitment and organizational fairness climate but on the other hand it has positive impact on career satisfaction and ethical leadership. H18 \& H19 is accepted as their p value is less than 0.05. Similarly table shows that H20, H34, H37 and H38 are accepted as these hypotheses have $\mathrm{p}$ value less than 0.05 and $t$ value greater than 2 . These hypotheses say that spirituality believe has positive impact on Affective commitment, Spirituality Practices has positive impact on ethical leadership, Tenour has positive impact on Organization fairness climate, and Career satisfaction. Rest of hypotheses are rejected for having $\mathrm{p}$ value less than 0.05 . 


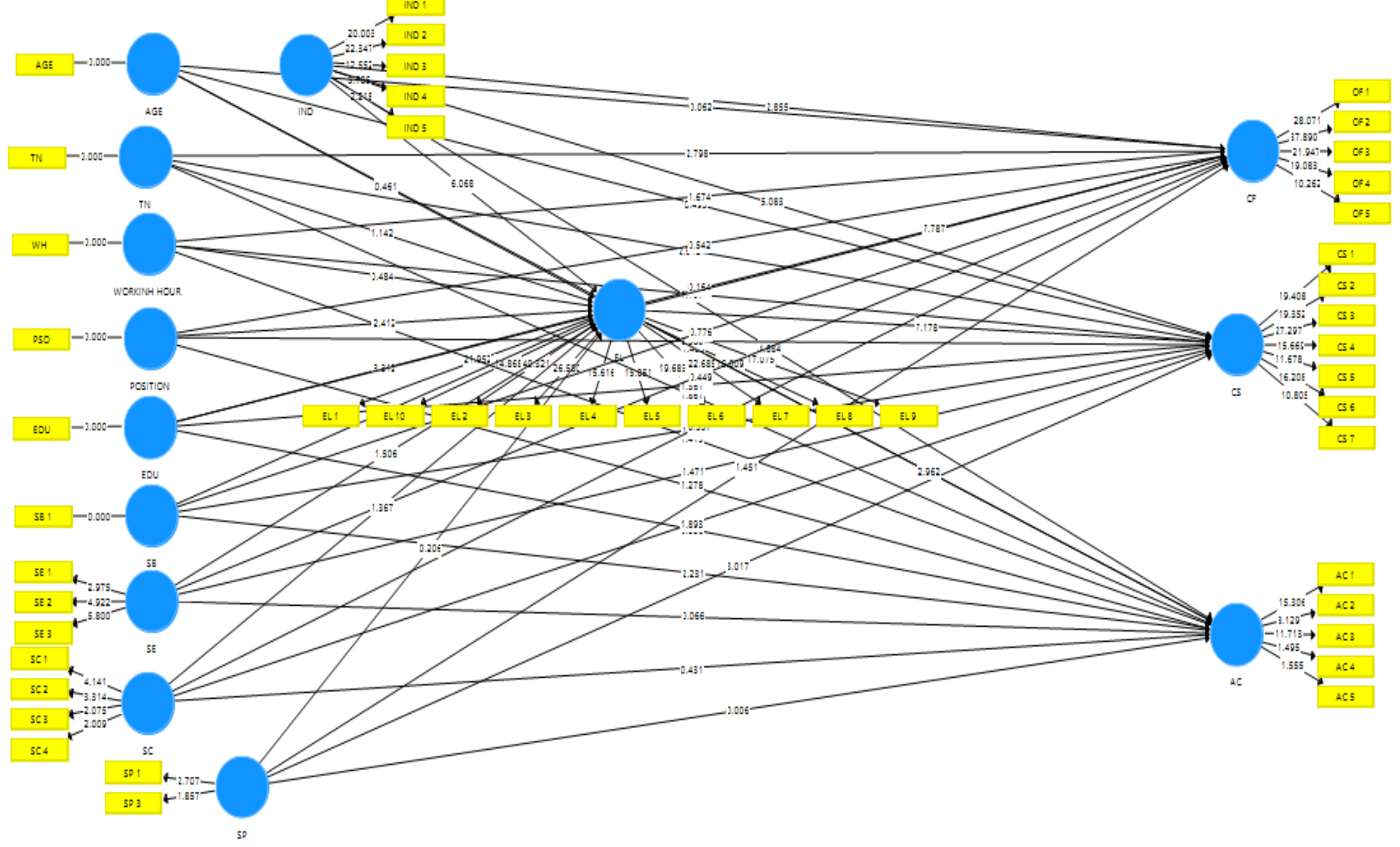

\begin{tabular}{|c|c|c|c|}
\hline Table 6: Path coefficient & $\begin{array}{l}\text { Origin } \\
\text { al } \\
\text { Sampl } \\
\text { e }(0)\end{array}$ & $\begin{array}{l}\text { T Statistics } \\
\text { (|O/STDE } \\
\text { V|) }\end{array}$ & $\begin{array}{l}\mathbf{P} \\
\text { Values }\end{array}$ \\
\hline $\begin{array}{l}\mathrm{H}_{1} \text { :There is an impact of ethical leadership on Organization } \\
\text { fairness climate }\end{array}$ & 0.458 & 7.787 & $\mathbf{0}$ \\
\hline $\begin{array}{l}\mathrm{H}_{2} \text { :There is an impact of ethical leadership on Career } \\
\text { satisfaction }\end{array}$ & 0.44 & 7.178 & $\mathbf{0}$ \\
\hline $\begin{array}{l}\mathrm{H}_{3} \text { :There is an impact of ethical leadership on Affective } \\
\text { commitment }\end{array}$ & 0.205 & 2.962 & 0.003 \\
\hline $\mathrm{H}_{4}$ :There is an impact of position on Career satisfaction & -0.236 & 3.38 & 0.001 \\
\hline $\mathrm{H}_{5}$ :There is an impact of position on Affective commitment & -0.085 & 1.278 & 0.202 \\
\hline $\begin{array}{l}\mathrm{H}_{6} \text { :There is an impact of position on Organization fairness } \\
\text { climate }\end{array}$ & -0.032 & 0.542 & 0.588 \\
\hline $\mathrm{H}_{7}$ :There is an impact of position on ethical leadership & 0.138 & 2.412 & 0.016 \\
\hline $\mathrm{H}_{8}$ : There is an impact of age on Career satisfaction & 0.028 & 0.493 & 0.622 \\
\hline $\mathrm{H}_{9}$ : There is an impact of age on Affective commitment & -0.082 & 1.403 & 0.161 \\
\hline $\begin{array}{l}\mathrm{H}_{10}: \text { There is an impact of age on Organization fairness } \\
\text { climate }\end{array}$ & -0.003 & 0.062 & 0.95 \\
\hline $\mathrm{H}_{11}$ : There is an impact of age on ethical leadership & 0.026 & 0.461 & 0.645 \\
\hline $\mathrm{H}_{12}$ : There is an impact of education on Career satisfaction & -0.071 & 1.361 & 0.174 \\
\hline
\end{tabular}




\section{Macrothink}

International Journal of Human Resource Studies

ISSN 2162-3058

2021, Vol. 11, No. 1

\begin{tabular}{|c|c|c|c|}
\hline $\begin{array}{l}\mathrm{H}_{13} \text { : There is an impact of education on Affective } \\
\text { commitment }\end{array}$ & 0.189 & 3.538 & \\
\hline $\begin{array}{l}\mathrm{H}_{14}: \text { There is an impact of education on Organization fairness } \\
\text { climate }\end{array}$ & 0.009 & 0.164 & 0.87 \\
\hline $\mathrm{H}_{15}$ : There is an impact of education on ethical leadership & 0.165 & 3.312 & 0.001 \\
\hline $\begin{array}{l}\mathrm{H}_{16}: \text { There is an impact of working hours on Career } \\
\text { satisfaction }\end{array}$ & -0.083 & 1.197 & 0.232 \\
\hline $\begin{array}{l}\mathrm{H}_{17} \text { :There is an impact of working hours on Affective } \\
\text { commitment }\end{array}$ & -0.082 & 1.413 & 0.158 \\
\hline $\begin{array}{l}\mathrm{H}_{18} \text { :There is an impact of working hours on Organization } \\
\text { fairness climate }\end{array}$ & -0.114 & 1.674 & 0.095 \\
\hline $\mathrm{H}_{19}$ :There is an impact of working hours on ethical leadership & -0.028 & 0.484 & 0.629 \\
\hline $\begin{array}{l}\mathrm{H}_{20}: \text { There is an impact of individualism on Career } \\
\text { satisfaction }\end{array}$ & 0.306 & 5.083 & $\mathbf{0}$ \\
\hline $\begin{array}{l}\mathrm{H}_{21}: \text { There is an impact of individualism on Affective } \\
\text { commitment }\end{array}$ & 0.309 & 4.684 & $\mathbf{0}$ \\
\hline $\begin{array}{l}\mathrm{H}_{22} \text { :There is an impact of individualism on Organization } \\
\text { fairness climate }\end{array}$ & 0.192 & 2.855 & 0.004 \\
\hline $\mathrm{H}_{23}$ :There is an impact of individualism on ethical leadership & 0.328 & 6.068 & $\mathbf{0}$ \\
\hline $\mathrm{H}_{24}$ :There is an impact of Tenure on Affective commitment & 0.123 & 1.867 & 0.062 \\
\hline $\begin{array}{l}\mathrm{H}_{25}: \text { There is an impact of Tenure on Organization fairness } \\
\text { climate }\end{array}$ & 0.194 & 2.798 & 0.005 \\
\hline $\mathrm{H}_{26}$ :There is an impact of Tenure on Career satisfaction & 0.199 & 2.942 & 0.003 \\
\hline $\mathrm{H}_{27}$ :There is an impact of Tenure on ethical leadership & -0.069 & 1.142 & 0.254 \\
\hline $\begin{array}{l}\mathrm{H}_{28} \text { :There is a positive impact of Spirituality Believe on } \\
\text { ethical leadership }\end{array}$ & 0.078 & 1.493 & 0.136 \\
\hline $\begin{array}{l}\mathrm{H}_{29} \text { :There is a positive impact of Spirituality Believe on } \\
\text { Career satisfaction }\end{array}$ & -0.079 & 1.6 & 0.11 \\
\hline $\begin{array}{l}\mathrm{H}_{30} \text { :There is a positive impact of Spirituality Believe on } \\
\text { Affective commitment }\end{array}$ & 0.141 & 2.231 & 0.026 \\
\hline $\begin{array}{l}\mathrm{H}_{31} \text { :There is a positive impact of Spirituality Believe on } \\
\text { Organization fairness climate }\end{array}$ & 0.046 & 0.776 & 0.438 \\
\hline $\begin{array}{l}\mathrm{H}_{32} \text { :There is a positive impact of Spirituality coping on } \\
\text { ethical leadership }\end{array}$ & -0.124 & 1.367 & 0.172 \\
\hline $\begin{array}{l}\mathrm{H}_{33} \text { :There is a positive impact of Spirituality coping on } \\
\text { Career satisfaction }\end{array}$ & 0.146 & 1.893 & 0.059 \\
\hline
\end{tabular}




\begin{tabular}{|c|c|c|c|}
\hline $\begin{array}{l}\mathrm{H}_{34}: \text { There is a positive impact of Spirituality coping on } \\
\text { Affective commitment }\end{array}$ & -0.043 & 0.431 & 0.667 \\
\hline $\begin{array}{l}\mathrm{H}_{35} \text { :There is a positive impact of Spirituality coping on } \\
\text { Organization fairness climate }\end{array}$ & 0.044 & 0.557 & 0.578 \\
\hline $\begin{array}{l}\mathrm{H}_{36} \text { :There is a positive impact of Spirituality Practices on } \\
\text { ethical leadership }\end{array}$ & -0.015 & 0.206 & 0.837 \\
\hline $\begin{array}{l}\mathrm{H}_{37} \text { :There is a positive impact of Spirituality Practices on } \\
\text { Career satisfaction }\end{array}$ & -0.219 & 3.017 & 0.003 \\
\hline $\begin{array}{l}\mathrm{H}_{38}: \text { There is a positive impact of Spirituality Practices on } \\
\text { Affective commitment }\end{array}$ & 0 & 0.006 & 0.995 \\
\hline $\begin{array}{l}\mathrm{H}_{39} \text { :There is a positive impact of Spirituality Practices on } \\
\text { Organization fairness climate }\end{array}$ & -0.097 & 1.451 & 0.147 \\
\hline $\begin{array}{l}\mathrm{H}_{40} \text { :There is a positive impact of Spirituality experiences on } \\
\text { ethical leadership }\end{array}$ & -0.123 & 1.506 & 0.133 \\
\hline $\begin{array}{l}\mathrm{H}_{41} \text { :There is a positive impact of Spirituality experiences on } \\
\text { Career satisfaction }\end{array}$ & 0.092 & 1.471 & 0.142 \\
\hline $\begin{array}{l}\mathrm{H}_{42} \text { :There is a positive impact of Spirituality experiences on } \\
\text { Affective commitment }\end{array}$ & -0.007 & 0.066 & 0.947 \\
\hline $\begin{array}{l}\mathrm{H}_{43} \text { :There is a positive impact of Spirituality experiences on } \\
\text { Organization fairness climate }\end{array}$ & 0.042 & 0.449 & 0.653 \\
\hline
\end{tabular}

\subsubsection{Mediating Effects}

Mediation analysis is used to test causal chain in which it is tried to find out how and where does one variable(X) affects the other(Y) and in turn that other factor(Y) affects the third one (M). This tells how and why relationship between two variables affects the third one. It is also known as indirect effect (Baron \& Kenny' s, 1986). Mediation analysis of this study is appended below. The below table shows that education has positive impact on ethical leadership and in return ethical leadership has positive impact on affective commitment. These variable has positive relationship among them as their $t$ value is greater than 2 and $p$ value is less than 0.05. Similarly, individualism has positive relationship with ethical leadership and ethical leadership in return impact affective commitment but in positive way. If we see table it tells that all variables are positively correlated with each other and have greater $t$ value and $\mathrm{p}$ value less than 0.05 but this is not the case with position, ethical leadership and affective commitment. These three variable has weak relationship among them, they don' $t$ impact each other. $\mathrm{P}$ value is 0.083 which is greater than 0.05 .

Table 7

\begin{tabular}{|l|l|l|} 
Est. & T & $\mathbf{P}$ \\
Stat & Values \\
\hline
\end{tabular}




\begin{tabular}{|l|r|r|r|}
\hline Education -> Ethical Leadership -> Affective Commitment & 0.034 & 2.385 & $\mathbf{0 . 0 1 7}$ \\
\hline Individualism -> Ethical Leadership -> Affective Commitment & 0.067 & 2.438 & $\mathbf{0 . 0 1 5}$ \\
\hline Position -> Ethical Leadership -> Affective Commitment & 0.028 & 1.738 & $\mathbf{0 . 0 8 3}$ \\
\hline Education -> Ethical Leadership -> Organizational Fairness Climate & 0.076 & 3.113 & $\mathbf{0 . 0 0 2}$ \\
\hline $\begin{array}{l}\text { Individualism -> Ethical Leadership -> Organizational Fairness } \\
\text { Climate }\end{array}$ & 0.150 & 4.300 & $\mathbf{0 . 0 0 0}$ \\
\hline Position -> Ethical Leadership -> Organizational Fairness Climate & 0.063 & 2.338 & $\mathbf{0 . 0 2 0}$ \\
\hline Education -> Ethical Leadership -> Career Satisfaction & 0.073 & 3.144 & $\mathbf{0 . 0 0 2}$ \\
\hline Individualism -> Ethical Leadership -> Career Satisfaction & 0.144 & 4.209 & $\mathbf{0 . 0 0 0}$ \\
\hline Position -> Ethical Leadership -> Career Satisfaction & 0.061 & 2.270 & $\mathbf{0 . 0 2 4}$ \\
\hline
\end{tabular}

\section{Discussion}

This study supports previous studies, as previous studies also suggested that individualism has positive relationship with personal independence. Individuals who themselves as independent and self-sufficient are less likely to involve in cooperative behavior (Evers \& Lakomski, 2013). Previous studies has suggested subordinates perception about ethical leadership has positive relationship with follower' s assessing of affective commitment of their own (Pucic, 2015). It was suggested by the Meyer and Allen's model that enhances the mechanism of personal accomplishment in followers through just and supportive supervision which in turn generates the feelings of connections, involvement, and recognition with the organization. Comparing previous studies to this study, with the help of data, and observations it clearly shows that individualism has positive relationship with ethical leadership, organization's fairness climate, affective commitment, organizational climate and career satisfaction (Walumbwa and Schaubroeck 2009; Piccolo et al. 2010). This means that is individual will think about their self-interest, their goals then this will result in positive impact on leadership, organization' s fairness climate, affective commitment, organizational climate and career satisfaction. This study doesn' t support previous studies as previous studies say that individualism has negative relationship with ethical leadership (Campion \& Wang, 2019). However, there are several studies which rejects null hypotheses of this study. One of the reason why individualism failed to testify hypothesis of this study is, it is seen as Individual characteristics such as personal values, beliefs, profiles, goals and, that is way it lacks managerial involvements.

The results shows that ethical leadership has positive relationship with affective commitment, organizational fairness climate, career satisfaction and ethical leadership as the t value of all these variables is greater than 2 and the $\mathrm{p}$ value is less than 0.05 . Therefore all hypotheses of ethical leadership are accepted and also supports previous studies. Studies have also shown that ethical leadership has positive relationship with collectivism but negative relationship with individualism (Ko, n.d.). It is proposed that spiritual belief, spiritual experience, spiritual coping, spiritual practices has positive relationship with ethical leaderships as spiritual beliefs act as outline to screen the information that leader considers, and how the impact of those beliefs is mitigated by the leader' s positive development, organizational framework and leadership style (Gehrke, 2008). (Campion \& Wang, 2019) discussed that ethical leadership 
is important in addressing ethical importance of the relationship for leaders and concurrently increasing relations for subordinates. When mediating effect of ethical leadership on organization' s fairness climate, affective commitment, organizational climate and career satisfaction was evaluated; it was found that that ethical leadership has positive relationship with all these variables. This means that if fair and ethical leadership is practiced then there will be good organization' $s$ fairness climate, enhanced affective commitment, better organizational climate and increased career satisfaction. This study supports the mediating effect of ethical leadership as proposed in previous studies (Phipps, 2012).

Analysis of the result tells that spiritual belief, spiritual experience, spiritual coping, spiritual practices has negative relationship with ethical leadership, organization' s fairness climate, affective commitment, organizational climate and career satisfaction. But spiritual belief has positive impact on affective commitment which means individual's spiritual beliefs can help him in building positive and strong relationship with his/her organization. Also spiritual practices has positive relationship with career satisfaction. This means spiritual practices of an individual can help him/her in being satisfied with his/her career. This result is in accordance with the previous studies as these studies suggests that spiritual belief, spiritual experience, spiritual coping, spiritual practices has negative relationship with ethical leadership, organization's fairness climate, affective commitment, organizational climate and career satisfaction. This mean that if spirituality is practiced or is observed then it will negatively affect ethical leadership, organization' s fairness climate, affective commitment, organizational climate and career satisfaction. This study doesn' $t$ support previous studies as previous studies say spiritual belief, spiritual experience, spiritual coping, spiritual practices has positive relationship with ethical leaderships as spiritual beliefs act as outline to screen the information that leader considers, and how the impact of those beliefs is mitigated by the leader's positive development, organizational framework and leadership style (Korac-Kakabadse et al., 2002).

\section{Conclusion}

This study investigated the effect of spirituality, demographics, and culture on career satisfaction, organizational fairness climate, and affective commitment in Pakistani organization while analyzing the mediatory role of ethical leadership. For this study data used was from primary sources and data was collected via online and physical survey .This is an explanatory research as this explains the effect of spirituality, demographics, and culture on career satisfaction, organizational fairness climate, and affective commitment. This study found out that spirituality has negative relationship with career satisfaction, organizational fairness climate, and affective commitment. And authors of related researches confirmed that a negative relationship between spirituality and other variables is observed especially in a developing country context like Pakistan. This study also found out that age which is a demographic factor has no impact on career satisfaction, organizational fairness climate, and affective commitment. On the other hand it was also analyzed that ethical leadership has positive relationship with career satisfaction, organizational fairness climate, and affective commitment. This supported previous studies as researches found positive relationship of ethical leadership with all variables which means the higher the ethical leadership the higher 
the career satisfaction, organizational fairness climate, and affective commitment.

Previous studies focused mostly on followers' demographic characteristics, especially there position or rank, there may be other important influences in like spirituality and culture, which were not covered before. Therefore this study argued that demographics like Job, experience, Age, Education, Position, and Working Hour of employees affect their perception of ethical leadership (EL) in the organization, and this perception, in turn, affect the three above mentioned outcomes. In the same way, spirituality and individualistic (IND) cultures also influence these outcomes through EL. This is a novel attempt as no previous study attempted to combine spirituality, and culture along with demographics as an antecedents in the mediating role of ethical leadership in employees based outcomes. Moreover, no previous study offered to explain this in Pakistani context. Hence, this would further extend the research frontier and provided a much-needed generalization.

This study can help leaders to manage their subordinates along with their spirituality and ethics. It is observed that leaders try to keep spirituality and leadership or they don' t like to talk in and implement their spiritual beliefs in leadership (Phipps, 2012, 2012). Ethical leadership shall be practiced in order to have better working environment and to have followers on leader' s side. Ethical leadership is one in which is governed by ethics, moral beliefs, dignity for others and respect for the rights of others (Pucic, 2015).

\section{References}

Alarcón, D., Sánchez, J. A., \& De Olavide, U. (2015, October). Assessing convergent and discriminant validity in the ADHD-R IV rating scale: User-written commands for Average Variance Extracted (AVE), Composite Reliability (CR), and Heterotrait-Monotrait ratio of correlations (HTMT). In Spanish STATA Meeting (Vol. 39). Universidad Pablo de Olavide.

Ashforth, B. E., \& Mael, F. (1989). Social identity theory and the organization. Academy of Management Review, 14(1), 20-39.

Avolio, B. J., \& Gardner, W. L. (2005). Authentic leadership development: Getting to the root of positive forms of leadership. The Leadership Quarterly, 16(3), 315-338.

Bandura, A. (1986). Fearful expectations and avoidant actions as coeffects of perceived self-inefficacy.

Barling, J. E., \& Kelloway, E. (1999). Young workers: Varieties of experience. American Psychological Association.

Bartholdi, J. J., \& Hackman, S. T. (2014). Warehouse and distribution science. Supply Chain and Logistics Institute,.

Bentler, P. M., \& Bonett, D. G. (1980). Significance tests and goodness of fit in the analysis of covariance structures. Psychological Bulletin, 88(3), 588.

Blau, P. M. (1964). Justice in social exchange. Sociological Inquiry, 34(2), 193-206. 


\section{Macrothink}

International Journal of Human Resource Studies

ISSN 2162-3058

2021, Vol. 11, No. 1

Brown, M. E., \& Treviño, L. K. (2006). Ethical leadership: A review and future directions. The Leadership Quarterly, 17(6), 595-616.

Brown, M. E., Treviño, L. K., \& Harrison, D. A. (2005). Ethical leadership: A social learning perspective for construct development and testing. Organizational Behavior and Human Decision Processes, 97(2), 117-134.

Brown, W. D., \& Brewer, J. E. (1998). Nonvolatile semiconductor memory technology: A comprehensive guide to understanding and to using NVSM devices (Vol. 6). Wiley-IEEE Press.

Campion, L. L., \& Wang, C. X. (2019b). Collectivism and Individualism: The Differentiation of Leadership. TechTrends, 63(3), 353-356. https://doi.org/10.1007/s11528-019-00399-x

Carmines, E. G., \& Zeller, R. A. (1979). Reliability and validity assessment (Vol. 17). Sage publications.

Carr, J. Z., Schmidt, A. M., Ford, J. K., \& DeShon, R. P. (2003). Climate perceptions matter: A meta-analytic path analysis relating molar climate, cognitive and affective states, and individual level work outcomes. Journal of Applied Psychology, 88(4), 605.

Chua, E. G., \& Gudykunst, W. B. (1987). Conflict resolution styles in low-and high-context cultures. Communication Research Reports, 4(1).

Corbett, J. M., \& Lee, J. (2006). The impact of downsizing on employees' affective commitment. Journal of Managerial Psychology.

Crittenden, V. L., Crittenden, W. F., \& Ajjan, H. (2019). Empowering women micro-entrepreneurs in emerging economies: The role of information communications technology. Journal of Business Research, 98, 191-203.

Cunningham, W. A., Preacher, K. J., \& Banaji, M. R. (2001). Implicit Attitude Measures: Consistency, Stability, and Convergent Validity. Psychological Science, 12(2), 163-170. https://doi.org/10.1111/1467-9280.00328

Detert, J. R., Treviño, L. K., \& Sweitzer, V. L. (2008). Moral disengagement in ethical decision making: A study of antecedents and outcomes. Journal of Applied Psychology, 93(2), 374.

Diamantopoulos, A., Sarstedt, M., Fuchs, C., Wilczynski, P., \& Kaiser, S. (2012). Guidelines for choosing between multi-item and single-item scales for construct measurement: A predictive validity perspective. Journal of the Academy of Marketing Science, 40(3), 434-449.

Drolet, A. L., \& Morrison, D. G. (2001). Do we really need multiple-item measures in service research? Journal of Service Research, 3(3), 196-204.

Erez, M., \& Earley, P. C. (1987). Comparative analysis of goal-setting strategies across cultures. Journal of Applied Psychology, 72(4), 658. 


\section{Macrothink}

International Journal of Human Resource Studies ISSN 2162-3058 2021, Vol. 11, No. 1

Evers, C. W., \& Lakomski, G. (2013a). Methodological individualism, educational administration, and leadership. Journal of Educational Administration and History, 45(2), 159-173.

Evers, C. W., \& Lakomski, G. (2013b). Methodological individualism, educational administration, and leadership. Journal of Educational Administration and History, 45(2), 159-173. https://doi.org/10.1080/00220620.2013.768969

Fornell, C., \& Larcker, D. F. (1981). Structural equation models with unobservable variables and measurement error: Algebra and statistics. Sage Publications Sage CA: Los Angeles, CA.

Fraser, N. (2007). Reframing justice in a globalizing world. Global Inequality: Patterns and Explanations, 252-272.

Frazier, P. A., Tix, A. P., \& Barron, K. E. (2004). Testing moderator and mediator effects in counseling psychology research. Journal of Counseling Psychology, 51(1), 115.

Fry, L. W. (2003). Toward a theory of spiritual leadership. The Leadership Quarterly, 14(6), 693-727.

Frykberg, R. G., Zgonis, T., Armstrong, D. G., Driver, V. R., Giurini, J. M., Kravitz, S. R., Landsman, A. S., Lavery, L. A., Moore, J. C., Schuberth, J. M., \& others. (2006). Diabetic foot disorders: A clinical practice guideline (2006 revision). The Journal of Foot and Ankle Surgery, 45(5), S1-S66.

Gardner, W. L., Avolio, B. J., Luthans, F., May, D. R., \& Walumbwa, F. (2005). “ Can you see the real me?" A self-based model of authentic leader and follower development. The Leadership Quarterly, 16(3), 343-372.

Gehrke, S. J. (2008). Leadership through meaning-making: An empirical exploration of spirituality and leadership in college students. Journal of College Student Development, 49(4), 351-359.

Gilardi, G., \& Sharf, I. (2002). Literature survey of contact dynamics modelling. Mechanism and Machine Theory, 37(10), 1213-1239.

Goldhirsch, A., Winer, E. P., Coates, A., Gelber, R., Piccart-Gebhart, M., Thürlimann, B., Senn, H.-J., Members, P., Albain, K. S., André, F., \& others. (2013). personalizing the treatment of women with early breast cancer: Highlights of the St Gallen International Expert Consensus on the Primary Therapy of Early Breast Cancer 2013. Annals of Oncology, 24(9), 2206-2223.

Gordon, A., \& Yukl, G. (2004). The future of leadership research: Challenges and opportunities. German Journal of Human Resource Management, 18(3), 359-365.

Gray Jr, L. E., Ostby, J., Furr, J., Price, M., Veeramachaneni, D. R., \& Parks, L. (2000). Perinatal exposure to the phthalates DEHP, BBP, and DINP, but not DEP, DMP, or DOTP, alters sexual differentiation of the male rat. Toxicological Sciences, 58(2), 350-365. 


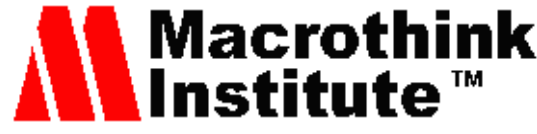

Hackett, R. D., Bycio, P., \& Hausdorf, P. A. (1994). Further assessments of Meyer and Allen' s (1991) three-component model of organizational commitment. Journal of Applied Psychology, 79(1), 15.

Hair, J. F., Risher, J. J., Sarstedt, M., \& Ringle, C. M. (2019). When to use and how to report the results of PLS-SEM. European Business Review, 31(1), 2-24. https://doi.org/10.1108/EBR-11-2018-0203

Haslam, S. A., Reicher, S. D., \& Platow, M. J. (2010). The new psychology of leadership: Identity, influence and power. Psychology Press.

Hassan, M. Q., Akhtar, M., Ahmed, S., Ahmad, A., \& Najmi, A. K. (2017). Nigella sativa protects against isoproterenol-induced myocardial infarction by alleviating oxidative stress, biochemical alterations and histological damage. Asian Pacific Journal of Tropical Biomedicine, 7(4), 294-299.

Henseler, J., Hubona, G., \& Ray, P. A. (2016). Using PLS path modeling in new technology research: Updated guidelines. Industrial Management \& Data Systems.

Henseler, J., Ringle, C. M., \& Sinkovics, R. R. (2009). The use of partial least squares path modeling in international marketing. In New challenges to international marketing. Emerald Group Publishing Limited.

Holly, S., \& Mohnen, A. (2012). Impact of working hours on work-life balance.

Judge, T. A., Weiss, H. M., Kammeyer-Mueller, J. D., \& Hulin, C. L. (2017). Job attitudes, job satisfaction, and job affect: A century of continuity and of change. Journal of Applied Psychology, 102(3), 356.

Kanungo, R. N., \& Mendonca, M. (1996a). Ethical dimensions of leadership (Vol. 3). Sage.

Kanungo, R. N., \& Mendonca, M. (1996b). Ethical dimensions of leadership (Vol. 3). Sage.

Kaplan, H., Hill, K., Lancaster, J., \& Hurtado, A. M. (2000). A theory of human life history evolution: Diet, intelligence, and longevity. Evolutionary Anthropology: Issues, News, and Reviews: Issues, News, and Reviews, 9(4), 156-185.

Kelloway, E., Barling, J., Harvey, S., \& Adams-Roy, J. (1999). Baseline assessment of ethical values in DND. Research report 99-14, Ottawa.

Kern, J., Chatterjee, R., Young, I. D., Fuller, F. D., Lassalle, L., Ibrahim, M., Gul, S., Fransson, T., Brewster, A. S., Alonso-Mori, R., \& others. (2018). Structures of the intermediates of Kok's photosynthetic water oxidation clock. Nature, 563(7731), 421-425.

Khan, S. B., Faisal, M., Rahman, M. M., \& Jamal, A. (2011). Exploration of CeO2 nanoparticles as a chemi-sensor and photo-catalyst for environmental applications. Science of the Total Environment, 409(15), 2987-2992.

Korac-Kakabadse, N., Kouzmin, A., \& Kakabadse, A. (2002). Spirituality and leadership praxis. Journal of Managerial Psychology. 


\section{Macrothink}

International Journal of Human Resource Studies ISSN 2162-3058 2021, Vol. 11, No. 1

Korac-Kakabadse, N., Kouzmin, A., \& Kakabadse, A. (2002). Spirituality and leadership praxis. Journal of Managerial Psychology, 17(3), 165-182. https://doi.org/10.1108/02683940210423079

Kriger, M. P., \& Hanson, B. J. (1999). A value-based paradigm for creating truly healthy organizations. Journal of Organizational Change Management.

Kriger, M., \& Seng, Y. (2005). Leadership with inner meaning: A contingency theory of leadership based on the worldviews of five religions. The Leadership Quarterly, 16(5), 771-806.

Levine, J., \& Butler, J. (1952). Lecture vs. Group decision in changing behavior. Journal of Applied Psychology, 36(1), 29.

Liu, J., Qiao, S. Z., Budi Hartono, S., \& Lu, G. Q. (2010). Monodisperse yolk- shell nanoparticles with a hierarchical porous structure for delivery vehicles and nanoreactors. Angewandte Chemie International Edition, 49(29), 4981-4985.

Lord, R. G., Foti, R. J., \& De Vader, C. L. (1984). A test of leadership categorization theory: Internal structure, information processing, and leadership perceptions. Organizational Behavior and Human Performance, 34(3), 343-378.

Machanavajjhala, A., Kifer, D., Abowd, J., Gehrke, J., \& Vilhuber, L. (2008). Privacy: Theory meets practice on the map. 2008 IEEE 24th International Conference on Data Engineering, 277-286.

Mason, C. H., \& Perreault, W. D. (1991). Collinearity, Power, and Interpretation of Multiple Regression Analysis. Journal of Marketing Research, 13.

Mayer, S. H. (2009). Development of a completely decentralized control system for modular continuous conveyors (Vol. 73). KIT Scientific Publishing.

Meyer, J. P., \& Allen, N. J. (1997). Commitment in the workplace: Theory, research, and application. Sage.

Meyer, J. P., Allen, N. J., \& Smith, C. A. (1993). Commitment to organizations and occupations: Extension and test of a three-component conceptualization. Journal of Applied Psychology, 78(4), 538.

Meyer, W., Biedermann, K., Gubo, M., Hammer, L., \& Heinz, K. (2008). Surface structure of polar Co3O4 (111) films grown epitaxially on Ir (100)-(1\$times\$ 1). Journal of Physics: Condensed Matter, 20(26), 265011.

Mishra, J., Dent, C., Tarabishi, R., Mitsnefes, M. M., Ma, Q., Kelly, C., Ruff, S. M., Zahedi, K., Shao, M., Bean, J., \& others. (2005). Neutrophil gelatinase-associated lipocalin (NGAL) as a biomarker for acute renal injury after cardiac surgery. The Lancet, 365(9466), 1231-1238. 


\section{$\triangle 1$ Macrothink}

International Journal of Human Resource Studies

ISSN 2162-3058

2021, Vol. 11, No. 1

Mohan, S., Heitzer, E., Ulz, P., Lafer, I., Lax, S., Auer, M., Pichler, M., Gerger, A., Eisner, F., Hoefler, G., \& others. (2014). Changes in colorectal carcinoma genomes under anti-EGFR therapy identified by whole-genome plasma DNA sequencing. PLoS Genet, 10(3), e1004271.

Mordini, F. E., Haddad, T., Hsu, L.-Y., Kellman, P., Lowrey, T. B., Aletras, A. H., Bandettini, W. P., \& Arai, A. E. (2014). Diagnostic accuracy of stress perfusion CMR in comparison with quantitative coronary angiography: Fully quantitative, semiquantitative, and qualitative assessment. JACC: Cardiovascular Imaging, 7(1), 14-22.

Neff, J. A. (2006). Exploring the dimensionality of "religiosity" and "spirituality" in the Fetzer multidimensional measure. Journal for the Scientific Study of Religion, 45(3), 449-459.

Olusanya, B. O., Osibanjo, F. B., \& Slusher, T. M. (2015). Risk factors for severe neonatal hyperbilirubinemia in low and middle-income countries: A systematic review and meta-analysis. PloS One, 10(2), e0117229.

Ostroff, C., \& Atwater, L. E. (2003). Does whom you work with matter? Effects of referent group gender and age composition on managers' compensation. Journal of Applied Psychology, 88(4), 725.

Perry, I. (2004). Prophets of the hood: Politics and poetics in hip hop. Duke University Press.

Phipps, K. A. (2012a). Spirituality and strategic leadership: The influence of spiritual beliefs on strategic decision making. Journal of Business Ethics, 106(2), 177-189.

Phipps, K. A. (2012b). Spirituality and Strategic Leadership: The Influence of Spiritual Beliefs on Strategic Decision Making. Journal of Business Ethics, 106(2), 177-189. https://doi.org/10.1007/s10551-011-0988-5

Piccolo, R. F., Greenbaum, R., Hartog, D. N. den, \& Folger, R. (2010). The relationship between ethical leadership and core job characteristics. Journal of Organizational Behavior, 31(2-3), 259-278.

Porter, L. W., Steers, R. M., Mowday, R. T., \& Boulian, P. V. (1974). Organizational commitment, job satisfaction, and turnover among psychiatric technicians. Journal of Applied Psychology, 59(5), 603.

Pucic, J. (2015). Do as I Say (and Do): Ethical Leadership Through the Eyes of Lower Ranks. Journal of Business Ethics, 129(3), 655-671. https://doi.org/10.1007/s10551-014-2190-z

Reave, L. (2005). Spiritual values and practices related to leadership effectiveness. The Leadership Quarterly, 16(5), 655-687.

Refaai, M. A., Fialkow, L. B., Heal, J. M., Henrichs, K. F., Spinelli, S. L., Phipps, R. P., Masel, E., Smith, B. H., Corsetti, J. P., Francis, C. W., \& others. (2011). An association of ABO non-identical platelet and cryoprecipitate transfusions with altered red cell transfusion needs in surgical patients. Vox Sanguinis, 101(1), 55-60. 


\section{Macrothink}

International Journal of Human Resource Studies ISSN 2162-3058 2021, Vol. 11, No. 1

Rhodes, S. R. (1983). Age-related differences in work attitudes and behavior: A review and conceptual analysis. Psychological Bulletin, 93(2), 328.

Ríos, A., Martínez-Alarcón, L., Sánchez, J., Jarvis, N., Parrilla, P., \& Ramírez, P. (2010). German citizens in southeastern Spain: A study of attitude toward organ donation. Clinical Transplantation, 24(3), 349-357.

Roberson, Q. M. (2006). Disentangling the meanings of diversity and inclusion in organizations. Group \& Organization Management, 31(2), 212-236.

Saunders, M. N. K., Lewis, P., \& Thornhill, A. (2009). Research methods for business students (5th ed). Prentice Hall.

Schneider, B. (1975). Organizational climates: An essay 1. Personnel Psychology, 28(4), 447-479.

Schneider, B., \& Bowen, D. E. (1985). Employee and customer perceptions of service in banks: Replication and extension. Journal of Applied Psychology, 70(3), 423.

Schneider, B., \& Snyder, R. A. (1975). Some relationships between job satisfaction and organization climate. Journal of Applied Psychology, 60(3), 318.

Schneider, L. S., Olin, J. T., Doody, R. S., Clark, C. M., Morris, J. C., Reisberg, B., Ferris, S. H., Schmitt, F. A., Grundman, M., \& Thomas, R. G. (1997). Validity and reliability of the Alzheimer's Disease Cooperative Study-Clinical global impression of change (ADCS-CGIC). In Alzheimer Disease (pp. 425-429). Springer.

Sherif, A. (2005). The aesthetics of speed and the illogicality of politics: Ishihara Shintarō's literary debut. Japan Forum, 17(2), 185-211.

Sherif, M., White, B. J., \& Harvey, O. J. (1955). Status in experimentally produced groups. American Journal of Sociology, 60(4), 370-379.

Shmueli, G., \& Koppius, O. R. (2011). Predictive analytics in information systems research. MIS Quarterly, 553- 572.

Shrout, P. E., \& Bolger, N. (2002). Mediation in experimental and non-experimental studies: New procedures and recommendations. Psychological Methods, 7(4), 422.

Simon, J. G. M. H. A. (1958). Organizations.

Smelt, S. C., Borrow, P., Kunz, S., Cao, W., Tishon, A., Lewicki, H., Campbell, K. P., \& Oldstone, M. B. (2001). Differences in affinity of binding of lymphocytic choriomeningitis virus strains to the cellular receptor $\alpha$-dystroglycan correlate with viral tropism and disease kinetics. Journal of Virology, 75(1), 448-457.

Smith, A., \& Hume, E. C. (2005). Linking culture and ethics: A comparison of accountants' ethical belief systems in the individualism/collectivism and power distance contexts. Journal of Business Ethics, 62(3), 209-220. 
Spears, L. C. (2010). Character and servant leadership: Ten characteristics of effective, caring leaders. The Journal of Virtues \& Leadership, 1(1), 25-30.

Super, D. E. (1953). A theory of vocational development. American Psychologist, 8(5), 185.

Tanyi, R. A. (2002). Towards clarification of the meaning of spirituality. Journal of Advanced Nursing, 39(5), 500-509.

Ting-Toomey, S. (1988). A face negotiation theory. Theory and Intercultural Communication, 47-92.

Toğrul, İ. T., \& Pehlivan, D. (2004). Modelling of thin layer drying kinetics of some fruits under open-air sun drying process. Journal of Food Engineering, 65(3), 413-425.

Triandis, H. C., Bontempo, R., Villareal, M. J., Asai, M., \& Lucca, N. (1988). Individualism and collectivism: Cross-cultural perspectives on self-ingroup relationships. Journal of Personality and Social Psychology, 54(2), 323.

Trusty, J., \& Brown, D. (2005). Advocacy competencies for professional school counselors. Professional School Counseling, 259-265.

Tschetter, E. (2014). Student satisfaction with online learning in higher education in the decade 2002-2012: A meta-analytic review. August.

Victor, B., \& Cullen, J. B. (1988). The organizational bases of ethical work climates. Administrative Science Quarterly, 101-125.

Wagner III, J. A. (1995). Studies of individualism-collectivism: Effects on cooperation in groups. Academy of Management Journal, 38(1), 152-173.

Wagner, J. A., \& Moch, M. K. (1986). Individualism-collectivism: Concept and measure. Group \& Organization Studies, 11(3), 280-304.

Walumbwa, F. O., \& Schaubroeck, J. (2009). Leader personality traits and employee voice behavior: Mediating roles of ethical leadership and work group psychological safety. Journal of Applied Psychology, 94(5), 1275.

Warr, P., Cook, J., \& Wall, T. (1979). Global job satisfaction scale. Taking the Measure of Work, Sage Publications, Thousand Oaks, CA.

Wherry, H. M. S. (2012). Authentic leadership, leader-member exchange, and organizational citizenship behavior: A multilevel analysis. Citeseer.

White, A. T., \& Spector, P. E. (1987). An investigation of age-related factors in the age-job-satisfaction relationship. Psychology and Aging, 2(3), 261.

Wright, T. A., \& Bonett, D. G. (2002). The moderating effects of employee tenure on the relation between organizational commitment and job performance: A meta-analysis. Journal of Applied Psychology, 87(6), 1183. 


\section{Macrothink}

International Journal of Human Resource Studies

ISSN 2162-3058

2021, Vol. 11, No. 1

Zhao, X., Lynch Jr, J. G., \& Chen, Q. (2010). Reconsidering Baron and Kenny: Myths and truths about mediation analysis. Journal of Consumer Research, 37(2), 197-206.

Zohar, D. (2000). A group-level model of safety climate: Testing the effect of group climate on microaccidents in manufacturing jobs. Journal of Applied Psychology, 85(4), 587.

\section{Appendix}

Appendix 1. Shows table 2 (Descriptive statistics): Mean, standard deviation (SD) and confirmatory factor analysis (CFA) along with the survey questions

\begin{tabular}{|c|c|c|c|c|c|c|}
\hline \multirow{2}{*}{$\begin{array}{l}\text { Variables \& } \\
\text { Factors }\end{array}$} & \multirow[b]{2}{*}{ Questions } & \multicolumn{2}{|c|}{ Descriptive Stats } & \multicolumn{3}{|c|}{ Confirmatory Factor Analysis } \\
\hline & & Mean & $\begin{array}{l}\text { Standard } \\
\text { Deviation }\end{array}$ & $\begin{array}{l}\text { Original } \\
\text { Sample }\end{array}$ & $\begin{array}{c}\text { T } \\
\text { Statistics }\end{array}$ & $\begin{array}{c}\mathbf{P} \\
\text { Values }\end{array}$ \\
\hline \multirow{5}{*}{$\begin{array}{c}\text { Affective } \\
\text { Commitment }\end{array}$} & $\begin{array}{l}\text { I would be very happy to spend the } \\
\text { rest of my career. }\end{array}$ & 0.802 & 0.058 & 0.819 & 14.088 & 0.000 \\
\hline & $\begin{array}{l}\text { I do not feel like "part of the family" } \\
\text { in the Forces. }\end{array}$ & 0.644 & 0.081 & 0.651 & 8.051 & 0.000 \\
\hline & $\begin{array}{l}\text { I really feel as if the organization's } \\
\text { problems are my own. }\end{array}$ & 0.695 & 0.060 & 0.711 & 11.783 & 0.000 \\
\hline & $\begin{array}{l}\text { I do not feel "emotionally attached" } \\
\text { to the organization }\end{array}$ & 0.252 & 0.173 & 0.283 & 1.635 & 0.103 \\
\hline & $\begin{array}{l}\text { I do not feel a strong sense of } \\
\text { "belonging" to the organization }\end{array}$ & 0.294 & 0.172 & 0.290 & 1.688 & 0.092 \\
\hline \multirow{7}{*}{$\begin{array}{c}\text { Career } \\
\text { Satisfaction }\end{array}$} & The military way of life. & 0.708 & 0.036 & 0.704 & 19.554 & 0.000 \\
\hline & Career progression & 0.732 & 0.037 & 0.736 & 19.985 & 0.000 \\
\hline & The promotion system. & 0.757 & 0.026 & 0.755 & 28.761 & 0.000 \\
\hline & $\begin{array}{l}\text { Recognition you receive from your } \\
\text { organization }\end{array}$ & 0.674 & 0.046 & 0.683 & 14.823 & 0.000 \\
\hline & $\begin{array}{l}\text { Opportunities for professional } \\
\text { development }\end{array}$ & 0.628 & 0.052 & 0.625 & 12.063 & 0.000 \\
\hline & Posting frequency & 0.671 & 0.042 & 0.672 & 15.863 & 0.000 \\
\hline & Working hours & 0.602 & 0.054 & 0.601 & 11.089 & 0.000 \\
\hline \multirow{7}{*}{$\begin{array}{c}\text { Ethical } \\
\text { Leadership }\end{array}$} & $\begin{array}{l}\text { Adheres to the policies and } \\
\text { procedures of the organization }\end{array}$ & 0.740 & 0.034 & 0.743 & 21.583 & 0.000 \\
\hline & Maintains order and discipline & 0.621 & 0.043 & 0.625 & 14.636 & 0.000 \\
\hline & $\begin{array}{l}\text { Discusses business ethics or values } \\
\text { with employees }\end{array}$ & 0.818 & 0.021 & 0.820 & 39.809 & 0.000 \\
\hline & $\begin{array}{l}\text { Supervisor treats me fairly when } \\
\text { decisions are being made }\end{array}$ & 0.771 & 0.030 & 0.772 & 26.041 & 0.000 \\
\hline & $\begin{array}{l}\text { Responds fairly to complaints and } \\
\text { concerns }\end{array}$ & 0.676 & 0.041 & 0.674 & 16.283 & 0.000 \\
\hline & Really cares about my well-being & 0.704 & 0.044 & 0.710 & 16.133 & 0.000 \\
\hline & $\begin{array}{l}\text { Encourages my personal and } \\
\text { professional development. }\end{array}$ & 0.731 & 0.035 & 0.731 & 20.858 & 0.000 \\
\hline
\end{tabular}




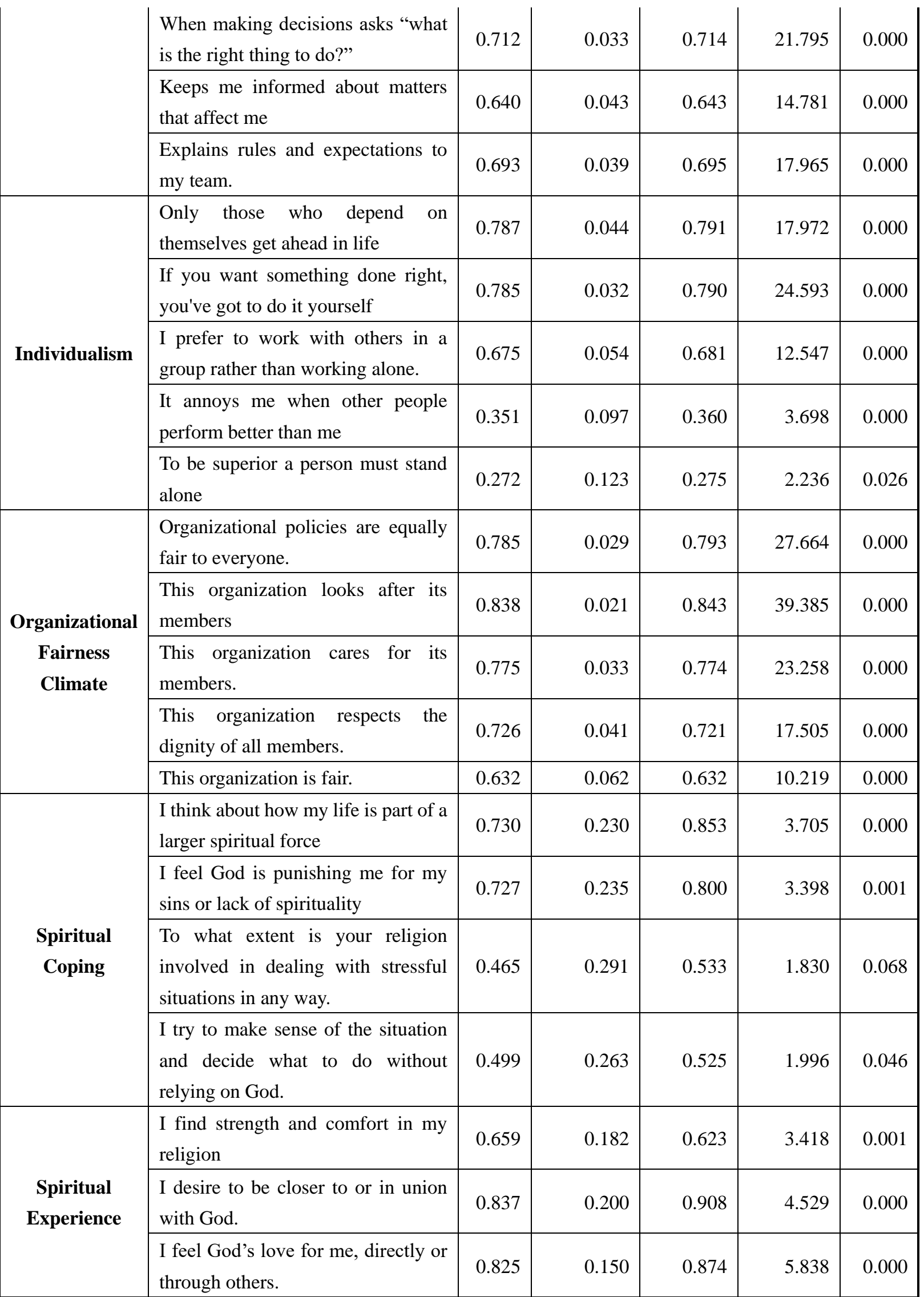




\section{Copyright Disclaimer}

Copyright for this article is retained by the author(s), with first publication rights granted to the journal.

This is an open-access article distributed under the terms and conditions of the Creative Commons Attribution license (http://creativecommons.org/licenses/by/4.0/). 